\title{
Maternal programming: Application of a developmental psychopathology perspective
}

\author{
LAURA M. GLYNN, ${ }^{a, b}$ MARIANN A. HOWLAND, ${ }^{b}$ AND MOLLY FOX ${ }^{c}$ \\ ${ }^{a}$ Chapman University; ${ }^{b}$ University of California, Irvine; and ${ }^{c}$ University of California, Los Angeles
}

\begin{abstract}
The fetal phase of life has long been recognized as a sensitive period of development. Here we posit that pregnancy represents a simultaneous sensitive period for the adult female with broad and persisting consequences for her health and development, including risk for psychopathology. In this review, we examine the transition to motherhood through the lens of developmental psychopathology. Specifically, we summarize the typical and atypical changes in brain and behavior that characterize the perinatal period. We highlight how the exceptional neuroplasticity exhibited by women during this life phase may account for increased vulnerability for psychopathology. Further, we discuss several modes of signaling that are available to the fetus to affect maternal phenotypes (hormones, motor activity, and gene transfer) and also illustrate how evolutionary perspectives can help explain how and why fetal functions may contribute to maternal psychopathology. The developmental psychopathology perspective has spurred advances in understanding risk and resilience for mental health in many domains. As such, it is surprising that this major epoch in the female life span has yet to benefit fully from similar applications.
\end{abstract}

The developmental psychopathology perspective provides a valuable framework for understanding mental health disorders and has particularly contributed to improved diagnosis and treatment for children and adolescents (Cicchetti \& Toth, 2009; Sroufe, 2013). Given that a central tenant of this approach is focus on characterizing normative development to inform understanding of atypical or aberrant psychology and behavior and that this approach is especially amenable to the investigation of transitional points in development across the life span (Toth \& Cicchetti, 2010), it is surprising that one significant developmental epoch in the female life span, that associated with the transition to motherhood, has yet to receive full benefit from this perspective (Bos, 2017; Goodman \& Dimidjian, 2012). The dynamic processes of pregnancy and lactation represent a developmental inflection point, one that is arguably the most fundamental and profound in the postnatal female life span. Pregnancy initiates broad and dramatic alterations in maternal anatomy, physiology, and metabolism (Strauss, Barbieri, \& Macy Ladd, 2014; Torgersen \& Curran, 2006; Williams, 2003). Among these changes is the growth and development of a new organ, the placenta, that has immune, endocrine, and vascular properties (Petraglia, Florio, Nappi, \& Genazzani, 1996). The pregnant woman exhibits endocrine alterations (the scope of which are unrivaled by any other in the postnatal

All three authors contributed equally to this manuscript. This work was supported by grants from the National Institutes of Health (MH-96889 and DK-105110).

Address correspondence and reprint requests to: Laura M. Glynn, Chapman University, Office of Research, One University Drive, Orange, CA 92866; E-mail: lgylnn@chapman.edu. life span), increases in blood volumes and cardiac output, hypercoagulation, insulin resistance, and a shift toward a Th-2 cytokine profile (Greer, 1999; Kuhl, 1991; Poole \& Claman, 2004; Torgersen \& Curran, 2006). These changes are among those comprising the extensive transformation of maternal physiology necessary to maintain the pregnancy and to prepare the maternal brain for the challenges of motherhood. However, to date, characterization of typical changes in human brain and behavior during pregnancy and the postpartum period are lacking, limiting the ability understand risk for psychopathology that may arise during this sensitive period of development. Nonetheless, here, we begin to address this issue by synthesizing what is known thus far about normative and pathological neuropsychological changes that occur during the peripartum period and how they relate to biological processes during this time.

\section{Maternal Programming: Typical Developmental Trajectories Associated With Motherhood}

It has long been recognized that the fetal period represents a sensitive phase in the human life span. However, what is less frequently acknowledged is that pregnancy and the postpartum period represent sensitive periods of neurological development for the mother as well (Glynn \& Sandman, 2011). There exists a very well-articulated literature describing maternal changes in brain and behavior in nonhuman animal species, particularly rodents. Leaders in this area of research have documented that as a result of pregnancy, delivery, lactation, and interaction with offspring, females show changes in a range of behavioral domains, such as fear response, 
aggression, receptiveness to pups, and also domains that more broadly support parental performance including memory and planning (Bridges, 1984; Fahrbach, Morrell, \& Pfaff, 1985; Kinsley et al., 1999; Li \& Fleming, 2003; Numan \& Insel, 2003; Numan, Rosenblatt, \& Komisaruk, 1977). The neurological systems that control the development and onset of maternal behavior also are well described (cf. Barrett \& Fleming, 2011; Bridges, 2015), and it is established that reproductive history is correlated with neuronal structure, signaling, and neurogenesis (Brummelte, Pawluski, \& Galea, 2006; Byrnes, Casey, \& Bridges, 2012; Byrnes, Casey, Carini, \& Bridges, 2013; Keyser-Marcus et al., 2001; Kinsley et al., 2006; Pfaff, Waters, Khan, Zhang, \& Numan, 2011; Shingo et al., 2003).

Despite evidence that most of these neurological changes in rodent mothers persist throughout the life span and may be cumulative (i.e., with additional each litter, the effects are magnified; Gatewood et al., 2005; Lemaire et al., 2006; Love et al., 2005), little is known about typical changes in the human female during this developmental period, although like other species, several physiological alterations implicated in brain function are apparent. For example, in humans and nonhuman primates, such as rodents, the prenatal endocrine milieu appears to set the stage for the onset and development of sensitive and effective maternal behavior (Bardi, French, Ramirez, \& Brent, 2004; Feldman, Weller, Zagoory-Sharon, \& Levine, 2007; Fleming, Ruble, Krieger, \& Wong, 1997; Glynn, Davis, Sandman, \& Goldberg, 2016; Maestripieri \& Zehr, 1998; Saltzman \& Abbott, 2009). Further, the hormone exposures of pregnancy predict attachment and persisting alterations in maternal behaviors that are detectable at least as late as the end of the first postpartum year (Glynn et al., 2016).

In addition to overtly maternal behaviors, another widely observed biobehavioral alteration coincident with motherhood is downregulation of stress responding, both physiological and behavioral, in humans (de Weerth \& Buitelaar, 2005; Glynn, Wadhwa, Dunkel Schetter, Chicz-Demet, \& Sandman, 2001) and other animals (Slattery \& Neumann, 2008; Vierin \& Bouissou, 2001; Wartella et al., 2003). During pregnancy, in humans, responsiveness of the hypothalamicpituitary-adrenal and sympathetic-adrenal-medullary systems are progressively dampened (Matthews \& Rodin, 1992; Nisell, Hjemdahl, Linde, \& Lunell, 1985a, 1985b; Schulte, Weisner, \& Allolio, 1990), and these changes are similarly observed in psychological responses to stressful challenges (Glynn, Dunker Schetter, Wadhwa, \& Sandman, 2004; Glynn et al., 2001). There is reason to believe that this downregulation of stress responding may serve to protect the mother and fetus from the adverse effects of acute stressors as pregnancy advances; women who do not show this typical change are at increased risk for preterm delivery (Buss et al., 2009; Glynn, Dunkel Schetter, Hobel, \& Sandman, 2008). The downregulated stress response then is sustained in the postpartum period by the endocrine profile of lactation (Heinrichs, Neumann, \& Ehlert, 2002) and also is coupled with enhanced aggression in response to threat, which may allow the mother to more successfully protect and provide for her offspring (Hahn-Holbrook, Holt-Lunstad, Holbrook, Coyne, \& Lawson, 2011). Additional capabilities to protect and tend to young successfully that have been documented in humans during pregnancy include deeper nonconscious processing of facial cues (Raz, 2014) and enhanced emotion recognition (Pearson, Lightman, \& Evans, 2009).

Unlike the concordance across species in the domain of stress responding and aggression, the patterns in the domain of cognitive function are somewhat less homologous. Among rodent mothers, pregnancy, or manipulation of hormones that simulate the prenatal endocrine milieu, result in enhanced spatial, working, and recognition memory, increased planning abilities, and a reduced latency to prey capture (Kinsley et al., 1999, 2014; Lambert et al., 2005; Macbeth, Gautreaux, \& Luine, 2008; Pawluski, Vanderbyl, Ragan, \& Galea, 2006). However, in humans, there is little evidence of enhanced function in these domains. Many memory and attentional functions appear to be unaffected by pregnancy in humans (Henry \& Rendell, 2007), and furthermore, it has been repeatedly documented that episodic and verbal recall memory are diminished (Glynn, 2010a, 2012; Henry \& Rendell, 2007). Much remains to be determined about what precise aspects of cognitive function are altered as a result of the transition to motherhood and also whether or not these alterations persist as they do throughout the life span in other nonhuman animals.

Most recently, researchers have begun to assess the neurological transformations supporting the transition to motherhood in humans (Kim, Leckman, Mayes, Feldman, et al., 2010; Kim, Leckman, Mayes, Newman, et al., 2010; Swain, Lorberbaum, Kose, \& Strathearn, 2007; Swain et al., 2008). Motherhood is associated with increased functional connectivity in regions that may subserve sensitive and responsive maternal behavior (Atzil, Hendler, \& Feldman, 2011; Atzil et al., 2017; Swain et al., 2017). Further, stronger intrinsic connectivity (functional connectivity between brain regions assessed with functional magnetic resonance imaging during a resting or task-free state) in the medial-amygdala network is associated with increased dopamine levels within this network, providing some of the first evidence among humans of dopaminergic mechanisms underlying human maternal behavior (Atzil et al., 2017). Most recent are findings documenting change in gray matter volumes from pre- to postpregnancy (Hoekzema et al., 2017). Specifically, changes in gray matter volume are related to maternal attachment and are observable at least 2 years after delivery. These emerging findings highlighting the neurological transformation of the human female, make a compelling case for additional investigation of the neural mechanisms that may underlie both risk and resilience for maternal psychopathology.

\section{Fetal Contributions to Maternal Developmental Trajectories}

In 1968, Bell published a seminal paper challenging existing models of the parent-child relationship as unidirectional, 
underscoring the reciprocal nature of the processes occurring between parent and child and permanently altering the way in which we characterize this unit. In contrast, this bidirectional conceptualization is largely ignored in the consideration of this unique relationship in the context of the prenatal period. While it is widely recognized that maternal signals shape the development of the fetus, it is not as widely acknowledged that this is only one side of the relationship and that fetal and placental signals also may shape the development of the maternal brain and behavior. In order for the fetus to effect change in maternal phenotypes, signals need to be transmitted from the intrauterine compartment into the maternal compartment. Several modes of signaling are available to the fetus and may transmit information across the fetal-maternal threshold. Abundant previous research has explored signal transmission in the opposite direction, but here we uniquely highlight three "languages" in which signals may be communicated from fetus to mother: (a) hormones; (b) motor activity; and (c) gene transfer.

\section{The maternal-fetal endocrine milieu}

The placenta is made up of mostly fetal tissue (villous chorion), and these fetal-identity cells (trophoblasts) produce hormones that are secreted into maternal circulation (Cuffe, Holland, Salomon, Rice, \& Perkins, 2017; Kliman, 1999; Mastorakos \& Ilias, 2003). Although there is understanding of how some fetal endocrine signals may influence the development of maternal behaviors and risk for psychopathology (discussed below), it remains largely unknown whether many hormones that are synthesized from the placenta and released into the maternal compartment are involved in shaping maternal phenotypes. This is the case for chorionic gonadotropin (Braunstein, Rasor, Adler, Danzer, \& Wade, 1976), activin (Muttukrishna, Child, Groome, \& Ledger, 1997; Petraglia et al., 1994), inhibin (Muttukrishna et al., 1997), relaxin (Eddie et al., 1986; Sakbun, Koay, \& Bryant-Greenwood, 1987; Tkachenko, Shchekochikhin, \& Schrier, 2014), leptin (Masuzaki et al., 1997), gonadotropin-releasing hormone (Siler-Khodr, Khodr, \& Valenzuela, 1984), and human placental lactogen (hPL; Kliman, 1994).

Other hormones that traverse the fetomaternal interface have more complicated derivations. Across many species during gestation, predictable and large increases in estrogens and progesterone are observed. Human serum estradiol and progesterone levels during pregnancy reflect placental and maternal (ovarian and adrenal) secretion; however, those observed in the maternal circulation are overwhelmingly of placental origin (Diczfalusy \& Troen, 1962). Placental estradiol and progesterone are interdependent with the maternal system (Mesiano, 2014); the precursor for placental steroid hormones is cholesterol extracted from both maternal and fetal circulation (Tuckey, 2005). Rodent models demonstrate the important role of sex steroid hormones in the onset and maintenance of maternal behaviors (Brunton \& Russell, 2008; Numan \& Insel, 2003; Saltzman \& Maestripieri,
2011). These connections between sex steroid exposures and quality of maternal behaviors also have been repeatedly observed among nonhuman primates, including tamarins, marmosets, titi monkeys, macaques, and baboons, as well as humans (Bardi, Shimizu, Barrett, Borgognini-Tarli, \& Huffman, 2003; Fleming, Ruble, et al., 1997; Glynn et al., 2016; Jarcho, Mendoza, \& Bales, 2012; Pryce, Abbott, Hodges, \& Martin, 1988).

Oxytocin (OT) is produced in the fetal compartment and secreted into the maternal bloodstream (Dawood, Wang, Gupta, \& Fuchs, 1978; Malek, Blann, \& Mattison, 1996), where it represents approximately $83 \%$ of circulating OT (Liu, 2013; Nakazawa, Makino, Iizuka, Kohsaka, \& Tsukada, 1984). Few longitudinal studies have assessed OT levels during pregnancy, but most of those have documented some evidence of increases across gestation (Dawood, Ylikorkala, Trivedi, \& Fuchs, 1979; De Geest, Thiery, PironPossoyt, \& Vanden Driessche, 1985; Levine, ZagoorySharon, Feldman, \& Weller, 2007; MacKinnon et al., 2014; Silber, Larsson, \& Uvnas-Moberg, 1991). OT is crucially involved in gestational and parturitional processes, but also implicated in a wide range of social and attachment behaviors (Bartz, Zaki, Bolger, \& Ochsner, 2011; Campbell, 2010; Heinrichs, von Dawans, \& Domes, 2009; Insel, 2010; Kirsch et al., 2005). The role of OT in controlling maternal behavior across species is experimentally evinced by studies in which intraventricular treatment with OT induces maternal behavior in virgin rats (Pedersen \& Prange, 1979), intracerebral administration of OT increases approach and touching of infants in macaques (Holman \& Goy, 1995), and peripheral administration of an OT antagonist reduces maternal interest in marmosets (Seltzer \& Ziegler, 2007). Similarly in humans, women who exhibit higher levels of OT during gestation and the early postpartum period report feeling closer and more attached to their fetuses, display enhanced theory of mind, and exhibit more infant directed gaze, affectionate touch, positive affect, and "motherese" vocalizations (Feldman et al., 2007; MacKinnon et al., 2014).

Corticotropin-releasing hormone (CRH) is a peptide hormone that is synthesized primarily in the paraventricular nucleus of the hypothalamus and plays a central role in regulating pituitary-adrenal function and the physiological response to stress (Vale, Spiess, Rivier, \& Rivier, 1981). The placenta, fetal membranes, and decidua all synthesize CRH (McLean \& Smith, 1999), but it is placental CRH that is released into maternal circulation, resulting in maternal plasma CRH levels that are 1000 times higher during pregnancy than in the nonpregnant state (Mesiano, 2014). In contrast to the inhibitory influence of maternal stress signals (e.g., cortisol) on expression of the CRH gene in the hypothalamus, maternal cortisol activates the promoter region of the gene in the placenta and stimulates CRH synthesis (King, Smith, \& Nicholson, 2001; Scatena \& Adler, 1998). Further, placental CRH stimulates the release of maternal ACTH, which is manufactured from its precursor proopiomelanocortin (POMC) that is partially derived from the placenta (Chen, Chang, Krieger, \& Bardin, 
1986). Maternal ACTH stimulates cortisol production, which then stimulates placental CRH (pCRH) synthesis and secretion (Mastorakos \& Ilias, 2003), resulting in a progressive increase in all three hormones across pregnancy. Although influences of $\mathrm{pCRH}$ on the regulation of maternal behaviors have yet to be documented, it is worth noting that through this placental signal the fetus could, hypothetically, manipulate maternal phenotypes indirectly through altering cortisol levels that have been implicated in maternal behavior and attachment in humans and other species (Bardi et al., 2004; Fleming, Steiner, \& Corter, 1997; Hennessy, Harney, Smotherman, Coyle, \& Levine, 1977; Rees, Panesar, Steinger, \& Fleming, 2004).

In addition to the roles of fetoplacental hormones in gestational physiology and onset of maternal psychology and behavior, variations in these hormone levels and trajectories have been implicated in risk for psychopathology. For example, it has been hypothesized that the rapidly declining levels of gonadal steroids may be implicated in postpartum depression (PPD) and postpartum psychosis among vulnerable women (Ahokas, Aito, \& Rimon, 2000; Bloch, Daly, \& Rubinow, 2003; Bloch et al., 2000; Wieck et al., 1991), midgestation maternal plasma OT concentrations have been associated with PPD (Skrundz, Bolten, Nast, Hellhammer, \& Meinlschmidt, 2011), and midgestation pCRH has been associated with depressive symptoms both during pregnancy and the postpartum period (Glynn \& Sandman, 2014; Rich-Edwards et al., 2008; Yim et al., 2009). These studies exemplify the possibility for fetal tissue-derived signals to be directly implicated in maternal psychopathology.

\section{Fetal behavior}

Although rarely considered, one additional pathway of potential fetal signaling is through fetal motor activity. Spontaneous fetal movement transiently stimulates maternal sympathetic arousal (DiPietro et al., 2006; DiPietro, Irizarry, Costigan, \& Gurewitsch, 2004). Further, experimentally evoking mild startle response in the fetus, which is characterized by increases motor activity, generates a transient maternal heart rate suppression and an increase in sympathetic activation (DiPietro et al., 2013). The mother does not appear to habituate to the fetal movement stimulus, which continues to invoke a maternal physiological response for the duration of gestation (DiPietro, Costigan, \& Voegtline, 2015). The precise biological pathway through which fetal movements might affect maternal arousal is currently unknown. However, it is unlikely that this occurs through conscious perception of these movements. At term, women detect as few as $16 \%$ of fetal movements (Johnson, Jordan, \& Paine, 1990), which is consistent with the fact that although they are relatively skilled at detecting large or prolonged fetal movements, pregnant women are limited in their ability to detect smaller spontaneous or evoked fetal movements (Kisilevsky, Killen, Muir, \& Low, 1991). Given that the pathway likely does not operate through conscious channels, DiPietro et al. (2004) propose that the most plausible mechanism is through perturbations of the uterine wall. They further suggest that these interactions may have broader implications for the role of the fetus in shaping maternal behavior, specifically suggesting that the sympathetic activation in response to the fetal movement signal may begin to prepare the female for the impending demands of motherhood by redirecting maternal resources away from competing but less relevant environmental demands. These findings and assertions raise the provocative question of whether the degree of prenatal synchrony between mother and fetus might set the stage for postnatal mother-infant interaction.

\section{Fetal microchimerism}

In 1979, Herzenberg, Bianchi, Schroder, Cann, and Iverson demonstrated the presence of cells containing a Y chromosome in the plasma of women who were pregnant with male fetuses. Subsequently, cells containing male DNA were demonstrated in the plasma of healthy women decades after giving birth to a son (Bianchi, Zickwolf, Weil, Sylvester, \& DeMaria, 1996), a phenomenon described as fetal microchimerism. During pregnancy, there is an asymmetric bidirectional exchange of maternal and fetal cells across the placental barrier (more fetal cells transferred to mother than vice versa; Lo, Lau, Chan, Leung, \& Chang, 2000). Fetal cells have been detected in a range of human maternal tissues, including thyroid, heart, liver, lungs, adrenals, kidneys, and bone marrow (Johnson et al., 2001; Khosrotehrani, Johnson, Cha, Salomon, \& Bianchi, 2004). A debate exists regarding the purpose of these fetal cells, and whether they exert salutary or detrimental influences on the mother's health and development (Boddy, Forunato, Sayres, \& Aktipis, 2015). For example, there is accumulating evidence that they may play a role in maternal wound healing (Mahmood \& O'Donoghue, 2014; Nassar et al., 2012), but these cells also have been identified at tumor sites (Kallenbach, Johnson, \& Bianchi, 2011) and have been associated with pregnancy complications (Gammill, Aydelotte, Guthrie, Nkwopara, \& Nelson, 2013; Gammill, Stephenson, Aydelotte, \& Nelson, 2014). Potentially relevant to the issue of maternal programming is the finding that, although the blood-brain barrier usually prevents the passage of cells, during pregnancy it appears that fetal cells may migrate to the maternal brain (Chan et al., 2012). These fetal cells are capable of taking on a range of attributes including neuron-, astrocyte- and oligodendrocyte-like cell types, conceivably allowing participation in neural circuitry and molecular communication (Tan et al., 2005; Zeng et al., 2010). Whether fetal cells in the maternal brain have any functional significance has yet to be demonstrated. Nonetheless, fetal cells are preferentially found in brain regions known to subserve maternal behavior, such as the olfactory bulb (Tan et al., 2005), raising the possibility that the attraction of fetal cells to specific brain areas could represent a pathway through which the fetus affects development and onset of maternal behavior and may have implications for risk for maternal psychopathology (Boddy et al., 2015; Glynn, 2010b). 


\section{Evolutionary Perspectives on Maternal Programming}

A hallmark of the developmental psychopathology perspective is the emphasis on an interdisciplinary approach. Viewing the maternal-fetal relationship in an evolutionary context can help explain why (and with what ultimate consequence) maternal biology, psychology, and behavior are responsive to fetal signals. Until the 1970s, maternal-fetal biology was generally presumed to reflect a synergistic, cooperative relationship, but Trivers (1974) reframed the parent-child relationship in terms of an evolutionary system of "parentoffspring conflict," which overturned the peaceful paradigm of maternal-fetal harmony.

Natural selection has shaped the process by which the fetus extracts resources from the mother, and how the mother provides for the fetus, but the evolutionary incentives of a mother and her fetus are slightly misaligned (Parker, Royle, $\&$ Hartley, 2002; Schrader \& Travis, 2009). This evolutionary tug-of-war is played out, at least mostly, unconsciously, so when we describe mother and offspring "interests" or assign agency to their "strategies," this is biological shorthand for describing the machinations of natural selection that favor perpetuation of certain allelic variants over others. From the mother's perspective, the adaptive value of investment (energy, time, and risk) in her pregnancy must be weighed against the costs (energy, attention, nutrition, and risk) to her existing children plus depletion of resources available for her future pregnancies. Meanwhile, selection on fetal traits prioritizes benefits to the fetus itself over the cost of impairing the mother from providing for its siblings and diminishing the likelihood of future siblings being born (Godfray, 1995). In this way, pregnancy becomes a battleground with mother and fetus selected to prefer different amounts of maternal investment, with selection promoting mutual manipulation.

How do the fetus and mother send, interpret, and respond to communication between each other if those messages have been selected to be, sometimes, misleading, threatening, or coercive (Haig, 1996)? Many hormones produced by the fetoplacental unit flow into maternal circulation. A large body of research in evolutionary ecology (particularly ornithology) has investigated how selection shapes the "honesty" of offspring-to-mother signals (Godfray, 1995; Kilner \& Johnstone, 1997). In competitive circumstances with limited resources, an offspring may compensate for her mother's and siblings' lower, compared to her own, optimal investment in her by exaggerating her needs (Royle, Hartley, \& Parker, 2002). For example, a nestling bird may beg in a way that indicates its need for food is far greater than it really is (Kilner, 1995; Kilner, Noble, \& Davies, 1999), because incomplete indulgence of an exaggerated request will (approximately) result in fulfillment of the needed amount. However, from the mother's point of view, if the fetus's honest needs cannot be distinguished from dishonest signals, the mother's best strategy is to ignore all signals (Haig, 1996). The ensuing selective forces can be framed as a game-theory cascade
(Bergstrom, 1995) in which fetus preempts anticipated maternal strategy by mimicking signals the mother uses to communicate between different parts of her body that govern the transfer of resources (Haig, 1993), producing hormones biochemically identical (e.g., CRH) or closely resembling (e.g., $\mathrm{hPL} /$ luteinizing hormone) nonplacental hormones, which the mother preempts by downregulating maternal production of those hormones (e.g., LH; progesterone) to isolate fetal signals, although the advantage of gaining conveyance between mother and fetus is balanced against the cost of losing conveyance between parts of the mother's body (Haig, 1996). Ultimately, the fetus is advantaged because placental hormones can "corrupt a mother's internal lines of communication" (Haig, 1993). Otherwise inexplicable enormous levels of placental hormones in maternal circulation may be due to this arms-race escalation from selection for fetal exploitation of maternal hormone receptors alongside selection for maternal resistance by downregulating receptor expression (Haig, 1993).

The mother's evolutionarily optimal investment in the offspring is, theoretically, calibrated to optimize her number of surviving descendants by balancing investment in her own health versus reproduction, and her current versus future pregnancies. This adaptive appraisal takes into account the mother's somatic resources (physical health and stored energy), number, ages, and quality (health and competence) of her current offspring, and the mother's own age and likelihood to have future offspring (Daly \& Wilson, 1995; Williams, 1966). The appraisal is a constantly updating assessment across a woman's reproductive life phase, as well as across the trajectory of any given reproductive event. For example, low-cost (to the mother in terms of time and energy investment) decision points, such delaying ovulation, are more sensitive to resource scarcity than high-cost decision points, such as spontaneous abortion, which poses a greater health risk to the mother and wastes the time and energy that was already devoted to that pregnancy. Mechanisms of intrinsic monitoring of somatic condition and age may include signals of cellular senescence such as telomere length and/or p53 and Rb protein levels (Ben-Porath \& Weinberg, 2005). Mechanisms of extrinsic monitoring of offspring condition and quantity are more difficult to identify but hypothetically could be linked to maternal hormones involved in gestation, lactation, social bonding, or stress.

The maternal-fetal conflict paradigm has broad implications for mental health during (and after) pregnancy. The endocrinology of pregnancy has been implicated in maternal psychological health (Beddoe, Paul Yang, Kennedy, Weiss, \& Lee, 2009; Glynn, Davis, \& Sandman, 2013), physical health (Magness, 1998; Schlomer, Del Giudice, \& Ellis, 2011), cognitive performance (Glynn, 2010b; Henry \& Sherwin, 2012), and behavior (Glynn et al., 2016), so fetal signaling, both honest and manipulative, may influence function in these domains. Moreover, the degree to which a mother valuates investing in her fetus versus current and future offspring varies between mothers and within a mother across her life 
span. Maternal-fetal conflict decreases as the mother's age increases, because of the inherently diminishing likelihood of future pregnancies (Trivers, 1974). This may result in more harmonious maternal attitudes and health outcomes for later-age mothers.

A woman's energetic investment or even emotional attachment to her fetus may be adaptively calibrated to respond to fetal "vigor," signals of survival likelihood such as health, strength, or size. The evolutionary cost of diverting time and resources away from current or future offspring and toward a fetus unlikely to survive may result in selection favoring maternal physiologic divestment strategies such as spontaneous abortion (Forbes, 1997; Nepomnaschy et al., 2006; Williams, 1966), behavioral divestment strategies such as limiting the mother's own food intake to feed her existing children more, or emotional divestment strategies. The area of women's mental health where these ideas have received the most attention is PPD (Thornhill \& Furlow, 1998). If the mother receives cues during (after) pregnancy of low fetal (neonatal) vigor, emotional and behavioral divestment from that one offspring may strategically enhance a woman's lifetime fertility (number of offspring) by allowing her to shift allocation of resources to instead invest in current or future offspring with higher likelihood of survivorship (Hagen, 1999, 2002). In this way, selection may have favored for women to respond to signals of poor fetal growth, for instance, with downregulated emotional bonding or even prenatal depression, in preparation for limiting investment in the fetus once it is born (via neglect, or in extreme cases, infanticide (Hagen, 1999, 2002). While these ideas remain controversial, they highlight how viewing maternal psychobiology within the context of evolutionary theory can be useful. The expectation that it is "natural" for women to bond with their fetus/baby and aberrations from this phenotype represent pathology that could be treated by tapping into some deep, innate instinct is misguided, and may partly explain the lack of efficacy in clinical strategies for preventing or treating antepartum and PPD (Dennis, 2005).

\section{Intergenerational Transmission of Maternal Phenotypes}

Understanding developmental transitions requires a consideration of both proximal and distal influences (Lewis, 1999). While this manuscript mostly describes events that occur during a woman's parturient years of life, it is also important to acknowledge the fetal and early life development of a person who will later become a mother. An important characteristic of prenatal programming is that, while some of its influence is evident from the time of birth, it also exerts influence on neuro-psycho-physiologic systems in ways that manifest much later in life. In particular, prenatal programming influences lifelong responsivity to both intrinsic and extrinsic conditions, which may only become relevant once the apposite conditions are encountered. Maternal phenotypes appear to be plastic in a way that is sensitive to conditions the mother encountered during her own prenatal and early life development. In this way, prenatal programming and early life experiences of one generation can influence the prenatal programming of the next generation.

Women vary widely in the attributes that are involved in the psychological, behavioral, and physiological traits, proclivities, and abilities involved in motherhood. For example, women are differentially adept at sensing infant needs, communicating with and comforting their infants (Ainsworth, 1979; Meins, Fernyhough, Fradley, \& Tuckey, 2001), have variation in postpartum sleep difficulties (Hunter, Rychnovsky, \& Yount, 2009), and are differentially physiologically efficient with milk letdown (Neifert, Seacat, \& Jobe, 1985). The variance in human maternal phenotypes can be partially ascribed to intergenerational trends (Belsky, Jaffee, Sligo, Woodward, \& Silva, 2005; Chen \& Kaplan, 2001; Smith \& Farrington, 2004; Thornberry, Freeman-Gallant, Lizotte, Krohn, \& Smith, 2003). These maternal characteristics may be perpetuated across generations by a dynamic combination of environmental, educational, cultural, and biological influences. Although there is substantial evidence that these continuities can be attributed in part to learning processes, we emphasize that key aspects of maternal phenotypes are plastic and sensitive to early life programming. These include executive function (Buss, Davis, Hobel, \& Sandman, 2011), social competence, and affective profiles (Davis, Glynn, Waffarn, \& Sandman, 2011; Howland, Sandman, Glynn, Crippen, \& Davis, 2016; Lombardo et al., 2012), as well as the physiological mediators of mothering behavior, including stress endocrinology (Davis et al., 2011; Glover, O'Connor, \& O'Donnell, 2010), neural circuitry (Babenko, Kovalchuk, \& Metz, 2015; Meaney, Szyf, \& Seckl, 2007), and neurotransmitter/receptor sensitivity and expression (Herlenius \& Lagercrantz, 2004). Evidence from various mammalian species indicates that maternal behavioral phenotypes are plastic, sensitive to early life programming effects, and can be broadcast across generations without alteration to genetic code (Francis, Diorio, Liu, \& Meaney, 1999; Gonzalez, Lovic, Ward, Wainwright, \& Fleming, 2001; Maestripieri, Lindell, $\&$ Higley, 2007). A developmental psychology approach emphasizes these ontogenic, dynamically interacting aspects of psychological development (i.e., an ecological-transactional model of development; Cicchetti \& Toth, 1997). The multilevel, developmental programming influences on the psychological, behavioral, and physiological traits, proclivities, and abilities involved in motherhood exemplify the importance of acknowledging the dynamic interplay between influences and processes across not only an individual's life span but also across generations to understand the origins of maternal phenotypes.

\section{Maternal Programming: Implications for Psychopathology}

As discussed above, there is substantial plasticity in neurobiological systems regulating affective, cognitive and social 
functioning during the perinatal period (Duan, Cosgrove, \& Deligiannidis, 2017; Kim, Strathearn, \& Swain, 2016; Lonstein, Maguire, Meinlschmidt, \& Neumann, 2014; MosesKolko, Horner, Phillips, Hipwell, \& Swain, 2014; Rutherford, Wallace, Laurent, \& Mayes, 2015), ${ }^{1}$ resulting in heightened vulnerability for psychopathology. Most attention on risk for psychopathology during the transition to motherhood has been directed toward perinatal depression, which affects up to $20 \%$ of women (Gavin et al., 2005; O'Hara \& McCabe, 2013). Shortly after delivery, up to $85 \%$ of women experience a profile of symptoms known as postpartum blues or baby blues, characterized by dysphoric mood, mood fluctuations, crying, anxiety, insomnia, and irritability (O'Hara \& McCabe, 2013; O’Hara, Schlechte, Lewis, \& Wright, 1991). These subclinical symptoms usually resolve within 10-12 days, unless they develop into PPD (O'Hara \& McCabe, 2013). There is some evidence that the early postpartum period is a time of increased risk for major depressive episodes (although a debate exists regarding this issue; Di Florio et al., 2013; O’Hara, Zekoski, Philipps, \& Wright, 1990; Vesga-Lopez et al., 2008) and that PPD may be phenotypically distinct from depression occurring outside of the perinatal period. Specifically, sad mood may be less prominent (Bernstein et al., 2008), and anxiety symptoms appear to be more prominent (Hendrick, Altshuler, Strouse, \& Grosser, 2000; Ross, Gilbert Evans, Sellers, \& Romach, 2003).

Perinatal anxiety disorders are often overlooked (Farr, Dietz, O'Hara, Burley, \& Ko, 2014; Goodman, Watson, \& Stubbs, 2016; Ross \& McLean, 2006), despite that they are frequently comorbid with perinatal depression and may be more prevalent (Matthey, Barnett, Howie, \& Kavanagh, 2003; Reck et al., 2008; Ross et al., 2003; Ross \& McLean, 2006; Russell, Fawcett, \& Mazmanian, 2013). Anxieties during pregnancy and the postpartum period may be uniquely directed toward the health and safety of the fetus/infant or the maternal role/parenting abilities (Fallon, Halford, Bennett, \& Harrold, 2016; Martini et al., 2015; Phillips, Sharpe, Matthey, \& Charles, 2009). Pregnancy-specific anxiety is defined as anxiety related to maternal and fetal health, labor and delivery, and parenting and has been identified as a separate clinical phenomenon distinct from measures of general anxiety during pregnancy (Blackmore, Gustafsson, Gilchrist, Wyman, \& O'Connor, 2016; Dunkel Schetter \& Glynn, 2011; Dunkel Schetter \& Tanner, 2012; Kane, Dunkel Schetter, Glynn, Hobel, \& Sandman, 2014; Misri, Abizadeh, Sanders, $\&$ Swift, 2015). The peripartum period is also characterized by increased risk for onset or exacerbation of obsessivecompulsive disorder (OCD), with 40\%-80\% of women experiencing symptoms at subclinical levels (Maina, Albert, Bogetto, Vaschetto, \& Ravizza, 1999; Miller, Hoxha, Wisner, \& Gossett, 2015; Misri et al., 2015; Ross \& McLean, 2006; Russell et al., 2013; Zambaldi et al., 2009). The most common of these symptoms are obsessive concerns related

1. Hereafter we refer to the perinatal period as encompassing all of pregnancy and the first postpartum year. to accidentally or intentionally harming the fetus or infant. These intrusive, violent thoughts are more prevalent in peripartum-onset OCD than in OCD without peripartum onset (Uguz, Akman, Kaya, \& Cilli, 2007) and, along with other OCD symptoms, are also more common in perinatal depression as compared to nonperinatal depression (Altemus et al., 2012; Wisner, Peindl, Gigliotti, \& Hanusa, 1999).

Of the multiple forms of psychopathology for which the peripartum period confers heightened risk, the relative risk for onset and recurrence of bipolar disorder is most pronounced. The relative risk of first-time hospitalization for bipolar disorder is 23 times higher in the first postpartum month as compared to any other phase of the life span (Munk-Olsen, Laursen, Pedersen, Mors, \& Mortensen, 2006), and in women known to have bipolar disorder, rates of recurrence are 50\%-70\% (Viguera et al., 2000, 2007). In addition, women with first onset of unipolar depression during the postpartum period appear to be at higher risk for subsequent conversion to bipolar disorder as compared to women with non-postpartum onset (Munk-Olsen, Laursen, Meltzer-Brody, Mortensen, \& Jones, 2012; Sharma et al., 2014). Bipolar disorder can present as postpartum psychosis (Jones \& Craddock, 2001), which is considered a psychiatric emergency and is rare, with an estimated prevalence of 1-2 in 1,000 (Sit, Rothschild, $\&$ Wisner, 2006). Symptoms of postpartum psychosis include severe sleep disturbances, rapid fluctuations in mood, mood-incongruent delusions, hallucinations, disorganized behavior, obsessions about the infant, and cognitive symptoms like disorientation and confusion (Bergink, Rasgon, \& Wisner, 2016; Jones, Chandra, Dazzan, \& Howard, 2014; Sit et al., 2006). Psychotic symptoms can also occur at subclinical levels and are more common in women with postpartum-onset depression as compared to pregnancy-onset depression (Altemus et al., 2012).

Consistent with contemporary symptom-based, dimensional approaches to the study of psychiatric disorders (Cuthbert \& Insel, 2013), a developmental psychopathology perspective recognizes that psychopathology occurs on a continuum and that contextual factors are critical in defining boundaries between adaptive and maladaptive development along this continuum. For example, somatic symptoms related to sleep, energy, weight, and appetite that are characteristic of psychopathological conditions in non-perinatal phases can result from normative physiological processes of pregnancy and postpartum (Bernstein et al., 2008; Goodman \& Dimidjian, 2012; Howard et al., 2014; Matthey \& RossHamid, 2011; Misri et al., 2015; Nylen, Williamson, O'Hara, Watson, \& Engeldinger, 2013) and may not necessarily indicate psychopathology. Relatedly, symptoms such as heightened anxiety or preoccupation regarding the infant may be a normative feature of new motherhood and represent a healthy maternal response to the infant initially, promoting vigilance, threat detection, and harm avoidance (Leckman et al., 1999, 2004; Wisner et al., 1999). There is evidence of a normative trajectory of these symptoms, which appear to peak in the immediate postpartum period and then begin 
to diminish by 3-4 months postpartum (Fairbrother \& Woody, 2008; Kim, Mayes, Feldman, Leckman, \& Swain, 2013; Leckman et al., 1999). Excessive and prolonged worry, or, on the other end of the continuum, an absence of worry, may indicate psychopathology (Kim et al., 2016; Leckman et al., 2004). Furthermore, the content of these early parental preoccupations may determine their course, whereby positive, idealizing thoughts of the infant may promote positive outcomes (Leckman et al., 2004).

Perinatal psychopathology is complex, multiply determined, and heterogeneous in presentation and course. Multiple developmental pathways leading to various manifestations of perinatal psychopathology have been identified and include factors both specific and nonspecific to the peripartum period. Non-peripartum-specific risk factors include a history of psychopathology, low social support, stressful life events, low socioeconomic status, obstetric complications, and personality factors such as insecure attachment style and low self-esteem (Goodman et al., 2016; Goodman \& Tully, 2009; Howard et al., 2014; Martini et al., 2015; Milgrom et al., 2008; O'Hara \& McCabe, 2013; O'Hara \& Wisner, 2014; Paschetta et al., 2014; Robakis et al., 2016; Tebeka, Strat, \& Dubertret, 2016; Vesga-Lopez et al., 2008; Yim, Tanner Stapleton, Guardino, Hahn-Holbrook, \& Dunkel Schetter, 2015). The most consistently reported perinatal-specific risk factor is an increased sensitivity to the hormone changes of the peripartum period, with both reproductive and stress hormones implicated. Most of this work has focused on PPD (Bloch et al., 2000, 2003; Brummelte \& Galea, 2010; Glynn \& Sandman, 2014; Rich-Edwards et al., 2008; Skrundz et al., 2011), but there is also evidence for hormone sensitivity in the etiology of perinatal OCD (Labad et al., 2011; McDougle, Barr, Goodman, \& Price, 1999) and psychosis (Ahokas et al., 2000; Bergink et al., 2016; Wieck et al., 1991). Other less-studied but promising biomarkers include genetic and epigenetic (Costas et al., 2010; Guintivano, Arad, Gould, Payne, \& Kaminsky, 2014; Jones \& Craddock, 2007), inflammatory (Bergink et al., 2013; Kendall-Tackett, 2007; Yim et al., 2015), and circadian factors (Lewis, Foster, \& Jones, 2016; Sharma, 2003). Multidisciplinary approaches to understanding perinatal risk are warranted and should examine how biological, psychological, and social factors interact to shape developmental trajectories.

The timing of onset of perinatal psychopathology may also determine symptom profiles and course (Di Florio \& MeltzerBrody, 2015; Fisher et al., 2016; Martini et al., 2015; Postpartum Depression: Action Towards and Treatment Consortium, 2015). Perinatal psychopathology that is a recurrence or exacerbation of pre-peripartum symptoms may be distinguished from psychopathology with onset specifically linked to the perinatal period. For example, women with postpartum psychosis usually have one of two disease courses: postpartum psychosis as an extension of bipolar disorder, or isolated postpartum psychosis, with vulnerability only after childbirth (Bergink et al., 2016; Sit et al., 2006; Yonkers et al., 2004). Two distinct expressions of PPD are similarly indicated
(Kettunen, Koistinen, \& Hintikka, 2014), with those women exhibiting first-onset PPD at higher risk for subsequent PPD episodes as compared to women whose PPD represents a recurrence of previous non-perinatal depression (Cooper \& Murray, 1995).

As a sensitive window of development, the perinatal period may also confer opportunities for resilience to psychopathology. Resilience during this life phase may manifest as an absence of psychopathology despite risk, or as competence in the tasks associated with the transition to motherhood in the face of risk (cf. Masten, 2001). While little research has focused on mechanisms of maternal resilience during the peripartum period (Dunkel Schetter, 2011), several studies have identified social support as protective against perinatal depressive symptoms in high-risk women (deCastro, Hinojosa-Ayala, \& Hernandez-Prado, 2011; Howell, Mora, DiBonaventura, \& Leventhal, 2009; Ritter, Hobfoll, Lavin, Cameron, \& Hulsizer, 2000). Further research is needed to identify additional psychological, biological, social, and cultural factors that promote well-being in vulnerable women (Dunkel Schetter, 2011). Perinatal-specific mechanisms may be particularly interesting and important to consider. Psychological resilience factors such as self-esteem, mastery, and self-efficacy may be enhanced with opportunities for success in achieving the tasks of parenthood and therefore particularly relevant (Howell et al., 2009). It is also plausible that the physiological changes of pregnancy and the postpartum period protect against certain symptoms or conditions. As discussed above, pregnancy and lactation are characterized by downregulated stress responsivity, which may have direct implications for resilience to psychopathology in women at risk. Consistent with this possibility, one investigation observed markedly reduced symptomology in women with bipolar disorder, type I, during pregnancy as compared to before or after pregnancy (Grof et al., 2000). Furthermore, breastfeeding has been prospectively linked to reduced PPD symptoms (Hahn-Holbrook, Haselton, Dunkel Schetter, \& Glynn, 2013).

Collectively, existing studies highlight the importance of considering the unique features of the perinatal period that contribute to increased risk for and resilience to psychopathology and inform symptom trajectories. Furthermore, it is clear that there are multiple potential pathways of vulnerability for or protection from perinatal psychopathology. Attention to these distinctive features and differential pathways can advance our understanding not only of perinatal psychopathology but also of trajectories of risk and resilience for psychopathology across the life span. Finally, while most research has focused on the consequences of maternal perinatal psychopathology for the developmental trajectories of the offspring, consequences for the developing mother are important to consider in their own right.

\section{Conclusions}

A growing body of literature suggests a remarkable neural plasticity associated with reproductive experience. In 1971, 
Marian Diamond provided a striking example of such plasticity, by demonstrating that the cortical sizes of pregnant rats housed in impoverished conditions matched those of nonpregnant rats housed in enriched conditions (Diamond, Johnson, \& Ingram, 1971). For the first time, Diamond's work demonstrated that pregnancy remodels the architecture of the female brain. As with other sensitive developmental periods in the human life span, the transition to motherhood represents an epoch that is well suited for the application of a developmental psychopathology perspective. This is a period in which the context, including the singular embedded relationship with the fetus and the fact that maternal and fetal

\section{References}

Ahokas, A., Aito, M., \& Rimon, R. (2000). Positive treatment effect of estradiol in postpartum psychosis: A pilot study. Journal of Clinical Psychiatry, 61, 166-169.

Ainsworth, M. S. (1979). Infant-mother attachment. American Psychologist, 34, 932-937.

Altemus, M., Neeb, C. C., Davis, A., Occhiogrosso, M., Nguyen, T., \& Bleiberg, K. L. (2012). Phenotypic differences between pregnancy-onset and postpartum-onset major depressive disorder. Journal of Clinical Psychiatry, 73, e1485-e1491. doi:10.4088/JCP.12m07693

Atzil, S., Hendler, T., \& Feldman, R. (2011). Specifying the neurobiological basis of human attachment: Brain, hormones, and behavior in synchronous and intrusive mothers. Neuropsychopharmacology, 36, 26032615. doi:10.1038/npp.2011.172

Atzil, S., Touroutoglou, A., Rudy, T., Salcedo, S., Feldman, R., Hooker, J. M., . . B Barrett, L. F. (2017). Dopamine in the medial amygdala network mediates human bonding. Proceedings of the National Academy of Sciences of the United States of America, 114, 2361-2366. doi:10.1073/pnas.1612233114

Babenko, O., Kovalchuk, I., \& Metz, G. A. (2015). Stress-induced perinatal and transgenerational epigenetic programming of brain development and mental health. Neuroscience and Biobehavioral Reviews, 48, 70-91. doi:10.1016/j.neubiorev.2014.11.013

Bardi, M., French, J. A., Ramirez, S. M., \& Brent, L. (2004). The role of the endocrine system in baboon maternal behavior. Biological Psychiatry, 55, 724-732. doi:10.1016/j.biopsych.2004.01.002

Bardi, M., Shimizu, K., Barrett, G. M., Borgognini-Tarli, S. M., \& Huffman, M. A. (2003). Peripartum sex steroid changes and maternal style in rhesus and Japanese macaques. General and Comparative Endocrinology, 133, 323-331.

Barrett, J., \& Fleming, A. S. (2011). Annual Research Review: All mothers are not created equal: Neural and psychobiological perspectives on mothering and the importance of individual differences. Journal of Child Psychology and Psychiatry, 52, 368-397. doi:10.1111/j.14697610.2010.02306.x

Bartz, J. A., Zaki, J., Bolger, N., \& Ochsner, K. N. (2011). Social effects of oxytocin in humans: Context and person matter. Trends in Cognitive Sciences, 15, 301-309.

Beddoe, A. E., Paul Yang, C.-P., Kennedy, H. P., Weiss, S. J., \& Lee, K. A. (2009). The effects of mindfulness-based yoga during pregnancy on maternal psychological and physical distress. Journal of Obstetric, Gynecologic, and Neonatal Nursing, 38, 310-319. doi:10.1111/j.1552-6909. 2009.01023.x

Bell, R. Q. (1968). A reinterpretation of the direction of effects in studies of socialization. Psychological Review, 75, 81-95.

Belsky, J., Jaffee, S. R., Sligo, J., Woodward, L., \& Silva, P. A. (2005). Intergenerational transmission of warm-sensitive-stimulating parenting: A prospective study of mothers and fathers of 3-year-olds. Child Development, 76, 384-396.

Ben-Porath, I., \& Weinberg, R. A. (2005). The signals and pathways activating cellular senescence. International Journal of Biochemistry and Cell Biology, 37, 961-976. doi:10.1016/j.biocel.2004.10.013

Bergink, V., Burgerhout, K. M., Weigelt, K., Pop, V. J., de Wit, H., Drexhage, R. C., . . Drexhage, H. A. (2013). Immune system dysregulation in programming are proceeding in parallel, coupled with the unique developmental tasks requiring mastery by the new mother, result in a significant transformation that is not yet fully understood nor properly characterized in humans. Furthering our understanding of how typical development during this transition proceeds, along with the ways in which trajectories may deviate from the normative, can aid in the understanding of psychopathology and potential interventions. Similarly, understanding how psychopathological states manifest during pregnancy and the postpartum period can inform our understanding of this most fundamental transformation in the female life span.

first-onset postpartum psychosis. Biological Psychiatry, 73, 1000-1007. doi:10.1016/j.biopsych.2012.11.006

Bergink, V., Rasgon, N., \& Wisner, K. L. (2016). Postpartum psychosis: Madness, mania, and melancholia in motherhood. American Journal of Psychiatry, 173, 1179-1188. doi:10.1176/appi.ajp.2016.16040454

Bergstrom, T. C. (1995). On the evolution of altruistic ethical rules for siblings. American Economic Review, 85, 58-81.

Bernstein, I. H., Rush, A. J., Yonkers, K., Carmody, T. J., Woo, A., McConnell, K., \& Trivedi, M. H. (2008). Symptom features of postpartum depression: Are they distinct? Depression and Anxiety, 25, 20-26. doi:10.1002/da.20276

Bianchi, D. W., Zickwolf, G. K., Weil, G. J., Sylvester, S., \& DeMaria, M. A. (1996). Male fetal progenitor cells persist in maternal blood for as long as 27 years postpartum. Proceedings of the National Academy of Sciences, 93, 705-708

Blackmore, E. R., Gustafsson, H., Gilchrist, M., Wyman, C., \& O’Connor, T. G (2016). Pregnancy-related anxiety: Evidence of distinct clinical significance from a prospective longitudinal study. Journal of Affective Disorders, 197, 251-258. doi:10.1016/j.jad.2016.03.008

Bloch, M., Daly, R. C., \& Rubinow, D. R. (2003). Endocrine factors in the etiology of postpartum depression. Comprehensive Psychiatry, 44 234-246. doi:10.1016/S0010-440X(03)00034-8

Bloch, M., Schmidt, P. J., Danaceau, M., Murphy, J., Nieman, L., \& Rubinow, D. R. (2000). Effects of gonadal steroids in women with a history of postpartum depression. American Journal of Psychiatry, 157, 924-930.

Boddy, A. M., Forunato, A., Sayres, M., \& Aktipis, A. (2015). Fetal microchimerism and maternal health: A review and evolutionary analysis of cooperation and conflict beyond the womb. BioEssays, 37, 1106-1118.

Bos, P. A. (2017). The endocrinology of human caregiving and its intergenerational transmission. Development and Psychopathology, 29, 971999. doi:10.1017/S0954579416000973

Braunstein, G. D., Rasor, J., Adler, D., Danzer, H., \& Wade, M. E. (1976) Serum human chorionic gonadotropin levels throughout normal pregnancy. American Journal of Obstetrics and Gynecology, 126, 678-681.

Bridges, R. S. (1984). A quantitative analysis of the roles of dosage, sequence, and duration of estradiol and progesterone exposure in the regulation of maternal behavior in the rat. Endocrinology, 114, 930-940. doi:10.1210/endo-114-3-930

Bridges, R. S. (2015). Neuroendocrine regulation of maternal behavior. Frontiers in Neuroendocrinology, 36, 178-196. doi:10.1016/j.yfrne. 2014.11.007

Brummelte, S., \& Galea, L. A. (2010). Depression during pregnancy and postpartum: Contribution of stress and ovarian hormones. Progress in Neuro-Psychopharmacology and Biological Psychiatry, 34, 766-776. doi:10.1016/j.pnpbp.2009.09.006

Brummelte, S., Pawluski, J. L., \& Galea, L. A. (2006). High post-partum levels of corticosterone given to dams influence postnatal hippocampal cell proliferation and behavior of offspring: A model of post-partum stress and possible depression. Hormones and Behavior, 50, 370-382. doi:10.1016/j.yhbeh.2006.04.008

Brunton, P. J., \& Russell, J. A. (2008). The expectant brain: Adapting for motherhood. Nature Reviews Neuroscience, 9, 11-25. doi:10.1038/nrn2280 
Buss, C., Davis, E., Hobel, C., \& Sandman, C. (2011). Maternal pregnancyspecific anxiety is associated with child executive function at 6-9 years age. Stress, 14, 665-676.

Buss, C., Entringer, S., Reyes, J. F., Chicz-DeMet, A., Sandman, C. A., Waffarn, F., \& Wadhwa, P. D. (2009). The maternal cortisol awakening response in human pregnancy is associated with the length of gestation. American Journal of Obstetics and Gynecology, 201, e391-e398. doi:10.1016/j.ajog.2009.06.063

Byrnes, E. M., Casey, K., \& Bridges, R. S. (2012). Reproductive experience modifies the effects of estrogen receptor alpha activity on anxiety-like behavior and corticotropin releasing hormone mRNA expression. Hormones and Behavior, 61, 44-49. doi:10.1016/j.yhbeh.2011.10.001

Byrnes, E. M., Casey, K., Carini, L. M., \& Bridges, R. S. (2013). Reproductive experience alters neural and behavioural responses to acute oestrogen receptor alpha activation. Journal of Neuroendocrinology, 25, 12801289. doi:10.1111/jne. 12113

Campbell, A. (2010). Oxytocin and human social behavior. Personality and Social Psychology Review, 14, 281-295.

Chan, W. F., Gurnot, C., Montine, T. J., Sonnen, J. A., Guthrie, K. A., \& Nelson, J. L. (2012). Male microchimerism in the human female brain. PLOS ONE, 7, e45592. doi:10.1371/journal.pone.0045592

Chen, C. L., Chang, C. C., Krieger, D. T., \& Bardin, C. W. (1986). Expression and regulation of proopiomelanocortin-like gene in the ovary and placenta: Comparison with the testis. Endocrinology, 118, 2382-2389. doi:10.1210/endo-118-6-2382

Chen, Z. Y., \& Kaplan, H. B. (2001). Intergenerational transmission of constructive parenting. Journal of Marriage and Family, 63, 17-31.

Cicchetti, D., \& Toth, S. L. (1997). Transactional ecological systems in developmental psychopathology. In S. S. Luthar, J. A. Burack, D. Cicchetti, \& J. R. Weisz (Eds.), Developmental psychopathology: Perspectives on adjustment, risk, and disorder (pp. 317-349) New York: Cambridge University Press.

Cicchetti, D., \& Toth, S. L. (2009). The past achievements and future promises of developmental psychopathology: The coming of age of a discipline. Journal of Child Psychology and Psychiatry, 50, 16-25. doi:10.1111/j.1469-7610.2008.01979.x

Cooper, P. J., \& Murray, L. (1995). Course and recurrence of postnatal depression: Evidence for the specificity of the diagnostic concept. British Journal of Psychiatry, 166, 191-195.

Costas, J., Gratacos, M., Escaramis, G., Martin-Santos, R., de Diego, Y., Baca-Garcia, E., ... Sanjuan, J. (2010). Association study of 44 candidate genes with depressive and anxiety symptoms in post-partum women. Journal of Psychiatric Research, 44, 717-724. doi:10.1016/j.jpsychires.2009.12.012

Cuffe, J. S. M., Holland, O., Salomon, C., Rice, G. E., \& Perkins, A. V. (2017). Review: Placental derived biomarkers of pregnancy disorders. Placenta, 54(Supplement C), 104-110. doi:10.1016/j.placenta.2017.01.119

Cuthbert, B. N., \& Insel, T. R. (2013). Toward the future of psychiatric diagnosis: The seven pillars of RDoC. BMC Medicine, 11, 126. doi:10.1186/ 1741-7015-11-126

Daly, M., \& Wilson, M. (1995). Discriminative parental solicitude and the relevance of evolutionary models to the analysis of motivational systems. In S. Parmigiani \& F. S. vom Saal (Eds.), Infanticide and parental care (pp. 1269-1286) Chur, Switzerland: Harwood Academic.

Davis, E. P., Glynn, L. M., Waffarn, F., \& Sandman, C. A. (2011). Prenatal maternal stress programs infant stress regulation. Journal of Child Psychology and Psychiatry, 52, 119-129. doi:10.1111/j.1469-7610.2010.02314.x

Dawood, M., Wang, C., Gupta, R., \& Fuchs, F. (1978). Fetal contribution to oxytocin in human labor. Obstetrics and Gynecology, 52, 205-209.

Dawood, M. Y., Ylikorkala, O., Trivedi, D., \& Fuchs, F. (1979). Oxytocin in maternal circulation and amniotic fluid during pregnancy. Journal of Clinical Endocrinology and Metabolism, 49, 429-434.

deCastro, F., Hinojosa-Ayala, N., \& Hernandez-Prado, B. (2011). Risk and protective factors associated with postnatal depression in Mexican adolescents. Journal of Psychosomatic Obstetric Gynaecology, 32, 210217. doi:10.3109/0167482X.2011.626543

De Geest, K., Thiery, M., Piron-Possoyt, G., \& Vanden Driessche, R. (1985). Plasma oxytocin in human pregnancy and parturition. Journal of Perinatal Medicine, 13, 3-13.

Dennis, C. L. (2005). Psychosocial and psychological interventions for prevention of postnatal depression: Systematic review. BMJ, 331, 15.

de Weerth, C., \& Buitelaar, J. K. (2005). Physiological stress reactivity in human pregnancy-A review. Neuroscience and Biobehavioral Reviews, 29, 295-312. doi:10.1016/j.neubiorev.2004.10.005
Diamond, M. C., Johnson, R. E., \& Ingram, C. (1971). Brain plasticity induced by environment and pregnancy. International Journal of Neuroscience, 2, 171-178.

Diczfalusy, E., \& Troen, P. (1962). Endocrine functions of the human placenta. Vitamins and Hormones, 19, 229-311.

Di Florio, A., Forty, L., Gordon-Smith, K., Heron, J., Jones, L., Craddock, N., \& Jones, I. (2013). Perinatal episodes across the mood disorder spectrum. JAMA Psychiatry, 70, 168-175. doi:10.1001/jamapsychiatry.2013.279

Di Florio, A., \& Meltzer-Brody, S. (2015). Is postpartum depression a distinct disorder? Current Psychiatry Reports, 17, 76. doi:10.1007/ s11920-015-0617-6

DiPietro, J. A., Caulfield, L. E., Irizarry, R. A., Chen, P., Merialdi, M., \& Zavaleta, N. (2006). Prenatal development of intrafetal and maternal-fetal synchrony. Behavioral Neuroscience, 120, 687-701. doi:10.1037/ 0735-7044.120.3.687

DiPietro, J. A., Costigan, K. A., \& Voegtline, K. M. (2015). Studies in fetal behavior: Revisited, renewed, and reimagined. Monographs of the Society for Research and Child Development, 80, 1-94. doi:10.1111/ mono.v80.3

DiPietro, J. A., Irizarry, R. A., Costigan, K. A., \& Gurewitsch, E. D. (2004). The psychophysiology of the maternal-fetal relationship. Psychophysiology, 41, 510-520.

DiPietro, J. A., Voegtline, K. M., Costigan, K. A., Aguirre, F., Kivlighan, K., \& Chen, P. (2013). Physiological reactivity of pregnant women to evoked fetal startle. Journal of Psychosomatic Research, 75, 321-326. doi:10.1016/j.jpsychores.2013.07.008

Duan, C., Cosgrove, J., \& Deligiannidis, K. M. (2017). Understanding peripartum depression through neuroimaging: A review of structural and functional connectivity and molecular imaging research. Current Psychiatry Report, 19, 70. doi:10.1007/s11920-017-0824-4

Dunkel Schetter, C. (2011). Psychological science on pregnancy: Stress processes, biopsychosocial models, and emerging research issues. Annual Review of Psychology, 62, 531-558. doi:10.1146/annurev.psych.031809.130727

Dunkel Schetter, C., \& Glynn, L. M. (2011). Stress in pregnancy: Empirical evidence and theoretical issues to guide interdisciplinary research. In $\mathrm{R}$. Contrada \& A. Baum (Eds.), The handbook of stress science: Biology, psychology, and health (pp. 321-343) New York: Springer.

Dunkel Schetter, C., \& Tanner, L. (2012). Anxiety, depression and stress in pregnancy: Implications for mothers, children, research, and practice. Current Opinions in Psychiatry, 25, 141-148. doi:10.1097/YCO.0b013e3283503680

Eddie, L., Lester, A., Bennett, G., Bell, R., Geier, M., Johnston, P., \& Niall, H. (1986). Radioimmunoassay of relaxin in pregnancy with an analogue of human relaxin. Lancet, 327, 1344-1346.

Fahrbach, S. E., Morrell, J. I., \& Pfaff, D. W. (1985). Possible role for endogenous oxytocin in estrogen-facilitated maternal behavior in rats. Neuroendocrinology, 40, 526-532.

Fairbrother, N., \& Woody, S. R. (2008). New mothers' thoughts of harm related to the newborn. Archives of Women's Mental Health, 11, 221-229. doi:10.1007/s00737-008-0016-7

Fallon, V., Halford, J. C. G., Bennett, K. M., \& Harrold, J. A. (2016). The Postpartum Specific Anxiety Scale: Development and preliminary validation. Archives of Women's Mental Health, 19, 1079-1090. doi:10.1007/s00737-016-0658-9

Farr, S. L., Dietz, P. M., O’Hara, M. W., Burley, K., \& Ko, J. Y. (2014). Postpartum anxiety and comorbid depression in a population-based sample of women. Journal of Women's Health (Larchmt), 23, 120-128. doi:10.1089/ jwh.2013.4438

Feldman, R., Weller, A., Zagoory-Sharon, O., \& Levine, A. (2007). Evidence for a neuroendocrinological foundation of human affiliation: Plasma oxytocin levels across pregnancy and the postpartum period predict motherinfant bonding. Psychological Science, 18, 965-970. doi:10.1111/ j.1467-9280.2007.02010.x

Fisher, S. D., Wisner, K. L., Clark, C. T., Sit, D. K., Luther, J. F., \& Wisniewski, S. (2016). Factors associated with onset timing, symptoms, and severity of depression identified in the postpartum period. Journal of Affective Disorders, 203, 111-120. doi:10.1016/j.jad.2016.05.063

Fleming, A. S., Ruble, D., Krieger, H., \& Wong, P. Y. (1997). Hormonal and experiential correlates of maternal responsiveness during pregnancy and the puerperium in human mothers. Hormones and Behavior, 31, 145-158. doi:10.1006/hbeh.1997.1376

Fleming, A. S., Steiner, M., \& Corter, C. (1997). Cortisol, hedonics, and maternal responsiveness in human mothers. Hormones and Behavior, 32, 85-98. doi:10.1006/hbeh.1997.1407 
Forbes, L. S. (1997). The evolutionary biology of spontaneous abortion in humans. Trends in Ecology \& Evolution, 12, 446-450.

Francis, D., Diorio, J., Liu, D., \& Meaney, M. J. (1999). Nongenomic transmission across generations of maternal behavior and stress responses in the rat. Science, 286, 1155-1158.

Gammill, H. S., Aydelotte, T. M., Guthrie, K. A., Nkwopara, E. C., \& Nelson, J. L. (2013). Cellular fetal microchimerism in preeclampsia. Hypertension, 62, 1062-1067. doi:10.1161/HYPERTENSIONAHA.113.01486

Gammill, H. S., Stephenson, M. D., Aydelotte, T. M., \& Nelson, J. L. (2014). Microchimerism in recurrent miscarriage. Cellular and Molecular Iтmиnology, 11, 589-594. doi:10.1038/cmi.2014.82

Gatewood, J. D., Morgan, M. D., Eaton, M., McNamara, I. M., Stevens, L. F., Macbeth, A. H., . . Kinsely, C. H. (2005). Motherhood mitigates agingrelated decrements in learning and memory and positively affects brain aging in the rat. Brain Research Bulletin, 66, 91-98.

Gavin, N. I., Gaynes, B. N., Lohr, K. N., Meltzer-Brody, S., Gartlehner, G., \& Swinson, T. (2005). Perinatal depression: A systematic review of prevalence and incidence. Obstetrics and Gynecology, 106(5. Pt. 1), 1071-1083. doi:10.1097/01.AOG.0000183597.31630.db

Glover, V., O'Connor, T., \& O'Donnell, K. (2010). Prenatal stress and the programming of the HPA axis. Neuroscience and Biobehavioral Reviews, 35, 17-22.

Glynn, L. M. (2010a). Giving birth to a new brain: Hormone exposures of pregnancy influence human memory. Psychoneuroendocrinology, 35, 1148-1155. doi:10.1016/j.psyneuen.2010.01.015

Glynn, L. M. (2010b). Implications of maternal programming for fetal neurodevelopment. In A. W. Zimmermann \& S. L. Connors (Eds.), Maternal influences on fetal neurodevelopment: Clinical and research aspects. London: Springer.

Glynn, L. M. (2012). Increasing parity is associated with cumulative effects on memory. Journal of Women's Health (Larchmt), 21, 1038-1045. doi:10.1089/jwh.2011.3206

Glynn, L. M., Davis, E. P., \& Sandman, C. A. (2013). New insights into the role of perinatal HPA-axis dysregulation in postpartum depression. Neuropeptides, 47, 363-370.

Glynn, L. M., Davis, E. P., Sandman, C. A., \& Goldberg, W. A. (2016). Gestational hormone profiles predict human maternal behavior at 1-year postpartum. Hormones and Behavior, 85, 19-25. doi:10.1016/ j.yhbeh.2016.07.002

Glynn, L. M., Dunkel Schetter, C., Hobel, C. J., \& Sandman, C. A. (2008). Pattern of perceived stress and anxiety in pregnancy predicts preterm birth. Health Psychology, 27, 43-51. doi:10.1037/0278-6133.27.1.43

Glynn, L. M., Dunkel Schetter, C., Wadhwa, P. D., \& Sandman, C. A. (2004). Pregnancy affects appraisal of negative life events. Journal of Psychosomatic Research, 56, 47-52. doi:10.1016/S0022-3999(03)00133-8

Glynn, L. M., \& Sandman, C. A. (2011). Prenatal origins of neurological development: A critical period for fetus and mother. Current Directions in Psychological Science, 20, 384-389.

Glynn, L. M., \& Sandman, C. A. (2014). Evaluation of the association between placental corticotrophin-releasing hormone and postpartum depressive symptoms. Psychosomatic Medicine, 76, 355-362. doi:10.1097/ PSY.0000000000000066

Glynn, L. M., Wadhwa, P. D., Dunkel Schetter, C., Chicz-Demet, A., \& Sandman, C. A. (2001). When stress happens matters: Effects of earthquake timing on stress responsivity in pregnancy. American Journal of Obstetric Gynecology, 184, 637-642. doi:10.1067/mob.2001.111066

Godfray, H. (1995). Signaling of need between parents and young: Parentoffspring conflict and sibling rivalry. American Naturalist, 146, 1-24.

Godfray, H. C. J. (1995). Evolutionary theory of parent-offspring conflict. Nature, 376, 133-138

Gonzalez, A., Lovic, V., Ward, G. R., Wainwright, P. E., \& Fleming, A. S. (2001). Intergenerational effects of complete maternal deprivation and replacement stimulation on maternal behavior and emotionality in female rats. Developmental Psychobiology, 38, 11-32.

Goodman, J. H., Watson, G. R., \& Stubbs, B. (2016). Anxiety disorders in postpartum women: A systematic review and meta-analysis. Journal of Affective Disorders, 203, 292-331. doi:10.1016/j.jad.2016.05.033

Goodman, S. H., \& Dimidjian, S. (2012). The developmental psychopathology of perinatal depression: Implications for psychosocial treatment development and delivery in pregnancy. Canadian Journal of Psychiatry, 57, 530-536. doi:10.1177/070674371205700903

Goodman, S. H., \& Tully, E. C. (2009). Recurrence of depression during pregnancy: Psychosocial and personal functioning correlates. Depression and Anxiety, 26, 557-567. doi:10.1002/da.20421
Greer, I. A. (1999). Thrombosis in pregnany: Maternal and fetal issues. Lancet, 10, 1258-1265.

Grof, P., Robbins, W., Alda, M., Berghoefer, A., Vojtechovsky, M., Nilsson, A., \& Robertson, C. (2000). Protective effect of pregnancy in women with lithium-responsive bipolar disorder. Journal of Affective Disorders, $61,31-39$.

Guintivano, J., Arad, M., Gould, T. D., Payne, J. L., \& Kaminsky, Z. A. (2014). Antenatal prediction of postpartum depression with blood DNA methylation biomarkers. Molecular Psychiatry, 19, 560-567. doi: $10.1038 / \mathrm{mp} .2013 .62$

Hagen, E. H. (1999). The functions of postpartum depression. Evolution and Human Behavior, 20, 325-359.

Hagen, E. H. (2002). Depression as bargaining: The case postpartum. Evolution and Human Behavior, 23, 323-336.

Hahn-Holbrook, J., Haselton, M. G., Dunkel Schetter, C., \& Glynn, L. M. (2013). Does breastfeeding offer protection against maternal depressive symptomatology? A prospective study from pregnancy to 2 years after birth. Archives of Women's Mental Health, 16, 411-422. doi:10.1007/ s00737-013-0348-9

Hahn-Holbrook, J., Holt-Lunstad, J., Holbrook, C., Coyne, S. M., \& Lawson, E. T. (2011). Maternal defense: Breast feeding increases aggression by reducing stress. Psychological Science, 22, 1288-1295. doi:10.1177/ 0956797611420729

Haig, D. (1993). Genetic conflicts in human pregnancy. Quarterly Review of Biology, 68, 495-532.

Haig, D. (1996). Placental hormones, genomic imprinting, and maternalFetal communication. Journal of Evolutionary Biology, 9, 357-380.

Heinrichs, M., Neumann, I., \& Ehlert, U. (2002). Lactation and stress: Protective effects of breast-feeding in humans. Stress, 5, 195-203. doi: 1025389021000010530

Heinrichs, M., von Dawans, B., \& Domes, G. (2009). Oxytocin, vasopressin, and human social behavior. Frontiers in Neuroendocrinology, 30, $548-557$.

Hendrick, V., Altshuler, L., Strouse, T., \& Grosser, S. (2000). Postpartum and nonpostpartum depression: Differences in presentation and response to pharmacologic treatment. Depression and Anxiety, 11, 66-72.

Hennessy, M. B., Harney, K. S., Smotherman, W. P., Coyle, S., \& Levine, S (1977). Adrenalectomy-induced deficits in maternal retrieval in the rat. Hormones and Behavior, 9, 222-227.

Henry, J. D., \& Rendell, P. G. (2007). A review of the impact of pregnancy on memory function. Journal of Clinical and Experimental Neuropsychology, 29, 793-803. doi:10.1080/13803390701612209

Henry, J. F., \& Sherwin, B. B. (2012). Hormones and cognitive functioning during late pregnancy and postpartum: A longitudinal study. Behavioral Neuroscience, 126, 73-85. doi:10.1037/a0025540

Herlenius, E., \& Lagercrantz, H. (2004). Development of neurotransmitter systems during critical periods. Experimental Neurology, 190, 8-21.

Herzenberg, L. A., Bianchi, D. W., Schroder, J., Cann, H. M., \& Iverson, G. M. (1979). Fetal cells in the blood of pregnant women: Detection and enrichment by fluorescence-activated cell sorting. Proceedings of the National Academy of Sciences of the United States of America, 76, $1453-1455$.

Hoekzema, E., Barba-Muller, E., Pozzobon, C., Picado, M., Lucco, F., GarciaGarcia, D., . . . Vilarroya, O. (2017). Pregnancy leads to long-lasting changes in human brain structure. Nature Neuroscience, 20, 287-296. doi: $10.1038 / \mathrm{nn} .4458$

Holman, S. D., \& Goy, R. W. (1995). Experiential and hormonal correlates of care-giving in rhesus macaques. In C. R. Pryce, R. D. Martin, \& D. Skuse (Eds.), Motherhood in human and nonhuman primates (pp. 97-93) Basel: Karger.

Howard, L. M., Molyneaux, E., Dennis, C. L., Rochat, T., Stein, A., \& Milgrom, J. (2014). Non-psychotic mental disorders in the perinatal period. Lancet, 384, 1775-1788. doi:10.1016/S0140-6736(14)61276-9

Howell, E. A., Mora, P. A., DiBonaventura, M. D., \& Leventhal, H. (2009). Modifiable factors associated with changes in postpartum depressive symptoms. Archives of Women's Mental Health, 12, 113-120. doi:10.1007/s00737-009-0056-7

Howland, M. A., Sandman, C. A., Glynn, L. M., Crippen, C., \& Davis, E. P. (2016). Fetal exposure to placental corticotropin-releasing hormone is associated with child self-reported internalizing symptoms. Psychoneuroendocrinology, 67, 10-17. doi:10.1016/j.psyneuen.2016.01.023

Hunter, L. P., Rychnovsky, J. D., \& Yount, S. M. (2009). A selective review of maternal sleep characteristics in the postpartum period. Journal of Obstetric, Gynecologic, and Neonatal Nursing, 38, 60-68. 
Insel, T. R. (2010). The challenge of translation in social neuroscience: A review of oxytocin, vasopressin, and affiliative behavior. Neuron, $65,768-779$.

Jarcho, M. R., Mendoza, S. P., \& Bales, K. L. (2012). Hormonal and experiential predictors of infant survivorship and maternal behavior in a monogamous primate (Callicebus cupreus) American Journal of Primatology, 74, 462-470. doi:10.1002/ajp.22003

Johnson, K. L., Nelson, J. L., Furst, D. E., McSweeney, P. A., Roberts, D. J., Zhen, D. K., \& Bianchi, D. W. (2001). Fetal cell microchimerism in tissue from multiple sites in women with systemic sclerosis. Arthritis \& Rheumatism, 46, 1848-1854.

Johnson, T. R. B., Jordan, E. T., \& Paine, L. L. (1990). Doppler recordings of fetal movement: II. Comparison with maternal perception. Obstetrics and Gynecology, 76, 42-43.

Jones, I., Chandra, P. S., Dazzan, P., \& Howard, L. M. (2014). Bipolar disorder, affective psychosis, and schizophrenia in pregnancy and the post-partum period. Lancet, 384, 1789-1799. doi:10.1016/S01406736(14)61278-2

Jones, I., \& Craddock, N. (2001). Familiality of the puerperal trigger in bipolar disorder: Results of a family study. American Journal of Psychiatry, 158, 913-917. doi:10.1176/appi.ajp.158.6.913

Jones, I., \& Craddock, N. (2007). Searching for the puerperal trigger: Molecular genetic studies of bipolar affective puerperal psychosis. Psychopharmacology Bulletin, 40, 115-128.

Kallenbach, L. R., Johnson, K. L., \& Bianchi, D. W. (2011). Fetal cell microchimerism and cancer: A nexus of reproduction, immunology, and tumor biology. Cancer Research, 71, 8-12. doi:10.1158/0008-5472.CAN-100618

Kane, H. S., Dunkel Schetter, C., Glynn, L. M., Hobel, C. J., \& Sandman, C. A. (2014). Pregnancy anxiety and prenatal cortisol trajectories. Biological Psychology, 100, 13-19. doi:10.1016/j.biopsycho.2014.04.003

Kendall-Tackett, K. (2007). A new paradigm for depression in new mothers: The central role of inflammation and how breastfeeding and anti-inflammatory treatments protect maternal mental health. International Breastfeeding Journal, 2, 6. doi:10.1186/1746-4358-2-6

Kettunen, P., Koistinen, E., \& Hintikka, J. (2014). Is postpartum depression a homogenous disorder: Time of onset, severity, symptoms and hopelessness in relation to the course of depression. BMC Pregnancy Childbirth, 14, 402. doi:10.1186/s12884-014-0402-2

Keyser-Marcus, L., Stafisso-Sandoz, G., Gerecke, K., Jasnow, A., Nightingale, L., Lambert, K. G., . . Kinsley, C. H. (2001). Alterations of medial preoptic area neurons following pregnancy and pregnancy-like steroidal treatment in the rat. Brain Research Bulletin, 55, 737-745.

Khosrotehrani, K., Johnson, K. L., Cha, D. H., Salomon, R. N., \& Bianchi, D. W. (2004). Transfer of fetal cells with multilineage potential to maternal tissue. Journal of the American Medical Association, 292, 75-80.

Kilner, R. (1995). When do canary parents respond to nestling signals of need? Proceedings of the Royal Society of London B: Biological Sciences, 260, 343-348.

Kilner, R., \& Johnstone, R. A. (1997). Begging the question: Are offspring solicitation behaviours signals of need? Trends in Ecology \& Evolution, 12, 11-15. doi:10.1016/S0169-5347(96)10061-6

Kilner, R., Noble, D., \& Davies, N. (1999). Signals of need in parentoffspring communication and their exploitation by the common cuckoo. Nature, 397, 667-672.

Kim, P., Leckman, J. F., Mayes, L. C., Feldman, R., Wang, X., \& Swain, J. E. (2010). The plasticity of human maternal brain: Longitudinal changes in brain anatomy during the early postpartum period. Behavioral Neuroscience, 124, 695-700. doi:10.1037/a0020884

Kim, P., Leckman, J. F., Mayes, L. C., Newman, M. A., Feldman, R., \& Swain, J. E. (2010). Perceived quality of maternal care in childhood and structure and function of mothers' brain. Developmental Science, 13, 662-673. doi:10.1111/j.1467-7687.2009.00923.x

Kim, P., Mayes, L., Feldman, R., Leckman, J. F., \& Swain, J. E. (2013). Early postpartum parental preoccupation and positive parenting thoughts: Relationship with parent-infant interaction. Infant Mental Health Journal, 34, 104-116. doi:10.1002/imhj.21359

Kim, P., Strathearn, L., \& Swain, J. E. (2016). The maternal brain and its plasticity in humans. Hormones and Behavior, 77, 113-123. doi:10.1016/ j.yhbeh.2015.08.001

King, B. R., Smith, R., \& Nicholson, R. C. (2001). The regulation of human corticotrophin-releasing hormone gene expression in the placenta. Peptides, 22, 1941-1947.
Kinsley, C. H., Blair, J. C., Karp, N. E., Hester, N. W., McNamara, I. M., Orthmeyer, A. L., . . . Lambert, K. G. (2014). The mother as hunter: Significant reduction in foraging costs through enhancements of predation in maternal rats. Hormones and Behavior, 66, 649-654. doi:10.1016/ j.yhbeh.2014.09.004

Kinsley, C. H., Madonia, L., Gifford, G. W., Tureski, K., Griffin, G. R., Lowry, C., . . . Lambert, K. G. (1999). Motherhood improves learning and memory. Nature, 402, 137-138. doi:10.1038/45957

Kinsley, C. H., Trainer, R., Stafisso-Sandoz, G., Quadros, P., Marcus, L. K., Hearon, C., . . Lambert, K. G. (2006). Motherhood and the hormones of pregnancy modify concentrations of hippocampal neuronal dendritic spines. Hormones and Behavior, 49, 131-142. doi:10.1016/j.yhbeh.2005.05.017

Kirsch, P., Esslinger, C., Chen, Q., Mier, D., Lis, S., Siddhanti, S., . . MeyerLindenberg, A. (2005). Oxytocin modulates neural circuitry for social cognition and fear in humans. Journal of Neuroscience, 25, 1148911493.

Kisilevsky, B. S., Killen, H., Muir, D. W., \& Low, J. A. (1991). Maternal and ultrasound measurements of elicited fetal movements: A methodologic consideration. Obstetrics and Gynecology, 77, 889-892.

Kliman, H. J. (1994). Placental hormones. Infertility and Reproductive Medicine Clinics of North America, 5, 591-610.

Kliman, H. J. (1999). Trophoblast to human placenta. In E. Knobil, M. K. Skinner, \& J. Neill (Eds.), Encyclopedia of reproduction (Vol. 4, pp. 834-846) Amsterdam: Elsevier.

Kuhl, C. (1991). Insulin resistance in pregnancy and GDM: Implications for diagnosis and management. Diabetes, 40, 18-24.

Labad, J., Vilella, E., Reynolds, R. M., Sans, T., Cavalle, P., Valero, J., . . Gutierrez-Zotes, A. (2011). Increased morning adrenocorticotrophin hormone (ACTH) levels in women with postpartum thoughts of harming the infant. Psychoneuroendocrinology, 36, 924-928. doi:10.1016/j.psyneuen.2010.11.006

Lambert, K. G., Berry, A. E., Griffins, G., Amory-Meyers, E., Madonia-Lomas, L., Love, G., \& Kinsley, C. H. (2005). Pup exposure differentially enhances foraging ability in primiparous and nulliparous rats. Physiology and Behavior, 84, 799-806. doi:10.1016/j.physbeh.2005.03.012

Leckman, J. F., Feldman, R., Swain, J. E., Eicher, V., Thompson, N., \& Mayes, L. C. (2004). Primary parental preoccupation: Circuits, genes, and the crucial role of the environment. Journal of Neural Transmission (Vienna), 111, 753-771. doi:10.1007/s00702-003-0067-x

Leckman, J. F., Mayes, L. C., Feldman, R., Evans, D. W., King, R. A., \& Cohen, D. J. (1999). Early parental preoccupations and behaviors and their possible relationship to the symptoms of obsessive-compulsive disorder. Acta Psychiatrica Scandinavia, 396, 1-26.

Lemaire, V., Billard, J. M., Dutar, P., George, O., Piazza, P. V., Epelbaum, J., . . . Mayo, W. (2006). Motherhood-induced memory improvement persists across lifespan in rats but is abolished by a gestational stress. European Journal of Neuroscience, 23, 3368-3374.

Levine, A., Zagoory-Sharon, O., Feldman, R., \& Weller, A. (2007). Oxytocin during pregnancy and early postpartum: Individual patterns and maternal-fetal attachment. Peptides, 28, 1162-1169.

Lewis, K. J., Foster, R. G., \& Jones, I. R. (2016). Is sleep disruption a trigger for postpartum psychosis? British Journal of Psychiatry, 208, 409-411. doi:10.1192/bjp.bp.115.166314

Lewis, M. (1999). Contextualism and the issue of continuity. Infant Behavior and Development, 22, 431-444.

Li, M., \& Fleming, A. S. (2003). The nucleus accumbens shell is critical for normal expression of pup-retrieval in postpartum female rats. Behavioral Brain Research, 145, 99-111.

Liu, J. H. (2013). Endocrinology of pregnancy. In C. J. Lockwood, J. D. Iams, \& M. F. Greene (Eds.), Creasy and Resnik's maternal-fetal medicine: Principles and practice. Philadelphia: Elsevier Health Sciences.

Lo, Y. M., Lau, T. K., Chan, L. Y., Leung, T. N., \& Chang, A. M. (2000). Quantitative analysis of the bidirectional fetomaternal transfer of nucleated cells and plasma DNA. Clinical Chemistry, 46, 1301-1309.

Lombardo, M. V., Ashwin, E., Auyeung, B., Chakrabarti, B., Lai, M.-C., Taylor, K., . . . Baron-Cohen, S. (2012). Fetal programming effects of testosterone on the reward system and behavioral approach tendencies in humans. Biological Psychiatry, 72, 839-847.

Lonstein, J. S., Maguire, J., Meinlschmidt, G., \& Neumann, I. D. (2014). Emotion and mood adaptations in the peripartum female: Complementary contributions of GABA and oxytocin. Journal of Neuroendocrinology, 26, 649-664. doi:10.1111/jne.12188 
Love, G., Torrey, N., McNamara, I. M., Morgan, M., Banks, M., Hester, N. W., . . . Lambert, K. G. (2005). Maternal experience produces long-lasting behavioral modifications in the rat. Behavioral Neuroscience, 119 , 1084-1096.

Macbeth, A. H., Gautreaux, C., \& Luine, V. N. (2008). Pregnant rats show enhanced spatial memory, decreased anxiety, and altered levels of monoaminergic neurotransmitters. Brain Research, 1241, 136-147. doi:10.1016/ j.brainres.2008.09.006

MacKinnon, A. L., Gold, I., Feeley, N., Hayton, B., Carter, C. S., \& Zelkowitz, P. (2014). The role of oxytocin in mothers' theory of mind and interactive behavior during the perinatal period. Psychoneuroendocrinology, 48, 52-63. doi:10.1016/j.psyneuen.2014.06.003

Maestripieri, D., Lindell, S. G., \& Higley, J. D. (2007). Intergenerational transmission of maternal behavior in rhesus macaques and its underlying mechanisms. Developmental Psychobiology, 49, 165-171.

Maestripieri, D., \& Zehr, J. L. (1998). Maternal responsiveness increases during pregnancy and after estrogen treatment in macaques. Hormones and Behavior, 34, 223-230. doi:10.1006/hbeh.1998.1470

Magness, R. R. (1998). Maternal cardiovascular and other physiologic responses to the endocrinology of pregnancy. In F. W. Bazer (Ed.), Endocrinology of pregnancy (pp. 507-539) Totowa, NJ: Humana Press.

Mahmood, U., \& O'Donoghue, K. (2014). Microchimeric fetal cells play a role in maternal wound healing after pregnancy. Chimerism, 5, 40-52.

Maina, G., Albert, U., Bogetto, F., Vaschetto, P., \& Ravizza, L. (1999). Recent life events and obsessive-compulsive disorder (OCD): The role of pregnancy/delivery. Psychiatry Research, 89, 49-58.

Malek, A., Blann, E., \& Mattison, D. R. (1996). Human placental transport of oxytocin. Journal of Maternal-Fetal Medicine, 5, 245-255.

Martini, J., Petzoldt, J., Einsle, F., Beesdo-Baum, K., Hofler, M., \& Wittchen, H. U. (2015). Risk factors and course patterns of anxiety and depressive disorders during pregnancy and after delivery: A prospective-longitudinal study. Journal of Affective Disorders, 175, 385-395. doi:10.1016/j.jad.2015.01.012

Masten, A. S. (2001). Ordinary magic. Resilience processes in development. American Psychologist, 56, 227-238.

Mastorakos, G., \& Ilias, I. (2003). Maternal and fetal hypothalamic-pituitaryadrenal axes during pregnancy and postpartum. Annals of the New York Academy of Sciences, 997, 136-149. doi:10.1196/annals.1290.016

Masuzaki, H., Ogawa, Y., Sagawa, N., Hosoda, K., Matsumoto, T., Mise, H., . . Nakao, K. (1997). Nonadipose tissue production of leptin: Leptin as a novel placenta-derived hormone in humans. Nature Medicine, 3, 1029-1033.

Matthews, K. A., \& Rodin, J. (1992). Pregnancy alters blood pressure responses to psychological and physical challenge. Psychophysiology, 29, 232-240.

Matthey, S., Barnett, B., Howie, P., \& Kavanagh, D. J. (2003). Diagnosing postpartum depression in mothers and fathers: Whatever happened to anxiety? Journal of Affective Disorders, 74, 139-147.

Matthey, S., \& Ross-Hamid, C. (2011). The validity of DSM symptoms for depression and anxiety disorders during pregnancy. Journal of Affectve Disorders, 133, 546-552. doi:10.1016/j.jad.2011.05.004

McDougle, C. J., Barr, L. C., Goodman, W. K., \& Price, L. H. (1999). Possible role of neuropeptides in obsessive compulsive disorder. Psychoneuroendocrinology, 24, 1-24.

McLean, M., \& Smith, R. (1999). Corticotropin-releasing hormone in human pregnancy and parturition. Trends in Endocrinology and Metabolism, 10, 174-178.

Meaney, M. J., Szyf, M., \& Seckl, J. R. (2007). Epigenetic mechanisms of perinatal programming of hypothalamic-pituitary-adrenal function and health. Trends in Molecular Medicine, 13, 269-277.

Meins, E., Fernyhough, C., Fradley, E., \& Tuckey, M. (2001). Rethinking maternal sensitivity: Mothers' comments on infants' mental processes predict security of attachment at 12 months. Journal of Child Psychology and Psychiatry and Allied Disciplines, 42, 637-648.

Mesiano, S. (2014). The endocrinology of human pregnancy and fetal-placental neuroendocrine development. In J. F. Strauss \& R. Barbieri (Eds.), Yen and Jaffe's reproductive endocrinology: Physiology, pathophysiology, and clinical management (pp. 243-271) Philadelphia: Elsevier Saunders.

Milgrom, J., Gemmill, A. W., Bilszta, J. L., Hayes, B., Barnett, B., Brooks, J., . . Buist, A. (2008). Antenatal risk factors for postnatal depression: A large prospective study. Journal of Affective Disorders, 108, 147-157. doi:10.1016/j.jad.2007.10.014
Miller, E. S., Hoxha, D., Wisner, K. L., \& Gossett, D. R. (2015). Obsessions and compulsions in postpartum women without obsessive compulsive disorder. Journal of Women's Health (Larchmt), 24, 825-830. doi:10.1089/jwh.2014.5063

Misri, S., Abizadeh, J., Sanders, S., \& Swift, E. (2015). Perinatal generalized anxiety disorder: Assessment and treatment. Journal of Women's Health (Larchmt), 24, 762-770. doi:10.1089/jwh.2014.5150

Moses-Kolko, E. L., Horner, M. S., Phillips, M. L., Hipwell, A. E., \& Swain, J. E. (2014). In search of neural endophenotypes of postpartum psychopathology and disrupted maternal caregiving. Journal of Neuroendocrinology, 26, 665-684. doi:10.1111/jne.12183

Munk-Olsen, T., Laursen, T. M., Meltzer-Brody, S., Mortensen, P. B., \& Jones, I. (2012). Psychiatric disorders with postpartum onset: Possible early manifestations of bipolar affective disorders. Archives of General Psychiatry, 69, 428-434. doi:10.1001/archgenpsychiatry.2011.157

Munk-Olsen, T., Laursen, T. M., Pedersen, C. B., Mors, O., \& Mortensen, P. B (2006). New parents and mental disorders: A population-based register study. Journal of the American Medical Association, 296, 2582-2589. doi:10.1001/jama.296.21.2582

Muttukrishna, S., Child, T., Groome, N., \& Ledger, W. (1997). Source of circulating levels of inhibin A, pro alpha C-containing inhibins and activin A in early pregnancy. Human Reproduction (Oxford), 12, 1089-1093.

Nakazawa, K., Makino, T., Iizuka, R., Kohsaka, S., \& Tsukada, Y. (1984). Immunohistochemical study on oxytocin-like substance in the human placenta. Endocrinologia Japonica, 31, 763-768.

Nassar, D., Droitcourt, C., Mathieu-d'Argent, E., Kim, M. J., Khosrotehrani, K., \& Aractingi, S. (2012). Fetal progenitor cells naturally transferred through pregnancy participate in inflammation and angiogenesis during wound healing. FASEB Journal, 26, 149-157. doi:10.1096/fj.11-180695

Neifert, M. R., Seacat, J. M., \& Jobe, W. E. (1985). Lactation failure due to insufficient glandular development of the breast. Pediatrics, 76 , 823-828.

Nepomnaschy, P. A., Welch, K. B., McConnell, D. S., Low, B. S., Strassmann, B. I., \& England, B. G. (2006). Cortisol levels and very early pregnancy loss in humans. Proceedings of the National Academy of Sciences of the United States of America, 103, 3938-3942.

Nisell, H., Hjemdahl, P., Linde, B., \& Lunell, N. O. (1985a). Sympatho-adrenal and cardiovascular reactivity in pregnancy-induced hypertension: I. Responses to isometric exercise and a cold pressor test. British Journal of Obstetrics and Gynaecology, 92, 722-731.

Nisell, H., Hjemdahl, P., Linde, B., \& Lunell, N. O. (1985b). Sympathoadrenal and cardiovascular reactivity in pregnancy-induced hypertension: II Responses to tilting. American Journal Obstetrics and Gynecology, 152, 554-560.

Numan, M., \& Insel, T. R. (2003). The neurobiology of parental behavior New York: Springer.

Numan, M., Rosenblatt, J. S., \& Komisaruk, B. R. (1977). Medial preoptic area and onset of maternal behavior in the rat. Journal of Comparative Physiological Psychology, 91, 146-164.

Nylen, K. J., Williamson, J. A., O'Hara, M. W., Watson, D., \& Engeldinger, J. (2013). Validity of somatic symptoms as indicators of depression in pregnancy. Archives of Women's Mental Health, 16, 203-210. doi:10.1007/s00737-013-0334-2

O'Hara, M. W., \& McCabe, J. E. (2013). Postpartum depression: Current status and future directions. Annual Review of Clinical Psychology, 9, 379-407. doi:10.1146/annurev-clinpsy-050212-185612

O'Hara, M. W., Schlechte, J. A., Lewis, D. A., \& Wright, E. J. (1991). Prospective study of postpartum blues: Biologic and psychosocial factors. Archives of General Psychiatry, 48, 801-806.

O'Hara, M. W., \& Wisner, K. L. (2014). Perinatal mental illness: Definition, description and aetiology. Best Practice and Research: Clinical Obstetrics and Gynaecology, 28, 3-12. doi:10.1016/j.bpobgyn.2013.09.002

O'Hara, M. W., Zekoski, E. M., Philipps, L. H., \& Wright, E. J. (1990). Controlled prospective study of postpartum mood disorders: Comparison of childbearing and nonchildbearing women. Journal of Abnormal Psychology, 99, 3-15.

Parker, G. A., Royle, N. J., \& Hartley, I. R. (2002). Intrafamilial conflict and parental investment: A synthesis. Philosophical Transactions of the Royal Society of London B: Biological Sciences, 357, 295-307.

Paschetta, E., Berrisford, G., Coccia, F., Whitmore, J., Wood, A. G., Pretlove, S., \& Ismail, K. M. (2014). Perinatal psychiatric disorders: An overview. American Journal of Obstetrics and Gynecology, 210, 501-509. doi:10.1016/j.ajog.2013.10.009 
Pawluski, J. L., Vanderbyl, B. L., Ragan, K., \& Galea, L. A. (2006). First reproductive experience persistently affects spatial reference and working memory in the mother and these effects are not due to pregnancy or "mothering" alone. Behavioral Brain Research, 175, 157-165. doi:10.1016/ j.bbr.2006.08.017

Pearson, R. M., Lightman, S. L., \& Evans, J. (2009). Emotional sensitivity for motherhood: Late pregnancy is associated with enhanced accuracy to encode emotional faces. Hormones and Behavior, 56, 557-563. doi:10.1016/j.yhbeh.2009.09.013

Pedersen, C. A., \& Prange, A. J. J. (1979). Induction of maternal behavior in virgin rats after intracerebroventricular administration of oxytocin. Proceedings of the National Academy of Sciences of the United States of America, 76, 6661-6665.

Petraglia, F., Florio, P., Nappi, C., \& Genazzani, A. R. (1996). Peptide signaling in human placenta and membranes: Autocrine, paracrine, and endocrine mechanisms. Endocrine Reviews, 17, 156-186.

Petraglia, F., Gallinelli, A., de Vita, D., Lewis, K., Mathews, L., \& Vale, W. (1994). Activin at parturition: Changes of maternal serum levels and evidence for binding sites in placenta and fetal membranes. Obstetrics and Gynecology, 84, 278-282.

Pfaff, D., Waters, E., Khan, Q., Zhang, X., \& Numan, M. (2011). Minireview: Estrogen receptor-initiated mechanisms causal to mammalian reproductive behaviors. Endocrinology, 152, 1209-1217. doi:10.1210/ en.2010-1007

Phillips, J., Sharpe, L., Matthey, S., \& Charles, M. (2009). Maternally focused worry. Archives of Women's Mental Health, 12, 409-418. doi:10.1007/s00737-009-0091-4

Poole, J. A., \& Claman, H. N. (2004). Immunology of pregnancy: Implications for the mother. Clinical Review of Allergy and Immunology, 26, 161-170. doi:10.1385/CRIAI:26:3:161

Postpartum Depression: Action Towards Causes and Treatment (PACT) Consortium (2015). Heterogeneity of postpartum depression: A latent class analysis. Lancet Psychiatry, 2, 59-67. doi:10.1016/S22150366(14)00055-8

Pryce, C. R., Abbott, D. H., Hodges, J. K., \& Martin, R. D. (1988). Maternal behavior is related to prepartum urinary estradiol levels in red-bellied tamarin monkeys. Physiology and Behavior, 44, 717-726.

Raz, S. (2014). Behavioral and neural correlates of cognitive-affective function during late pregnancy: An event-related potentials study. Behavioral Brain Research, 267, 17-25. doi:10.1016/j.bbr.2014.03.021

Reck, C., Struben, K., Backenstrass, M., Stefenelli, U., Reinig, K., Fuchs, T., . . . Mundt, C. (2008). Prevalence, onset and comorbidity of postpartum anxiety and depressive disorders. Acta Psychiatrica Scandinavia, 118, 459-468. doi:10.1111/j.1600-0447.2008.01264.x

Rees, S. L., Panesar, S., Steinger, M., \& Fleming, A. S. (2004). The effects of adrenalectomy and corticosterone replacement on maternal behavior in the postpartum rat. Hormones and Behavior, 46, 411-419.

Rich-Edwards, J. W., Mohllajee, A. P., Kleinman, K., Hacker, M. R., Majzoub, J., Wright, R. J., \& Gillman, M. W. (2008). Elevated midpregnancy corticotropin-releasing hormone is associated with prenatal, but not postpartum, maternal depression. Journal of Clinical Endocrinology and Metabolism, 93, 1946-1951. doi:10.1210/jc.2007-2535

Ritter, C., Hobfoll, S. E., Lavin, J., Cameron, R. P., \& Hulsizer, M. R. (2000). Stress, psychosocial resources, and depressive symptomatology during pregnancy in low-income, inner-city women. Health and Psychology, 19, 576-585.

Robakis, T. K., Williams, K. E., Crowe, S., Lin, K. W., Gannon, J., \& Rasgon, N. L. (2016). Maternal attachment insecurity is a potent predictor of depressive symptoms in the early postnatal period. Journal of Affective Disorders, 190, 623-631. doi:10.1016/j.jad.2015.09.067

Ross, L. E., Gilbert Evans, S. E., Sellers, E. M., \& Romach, M. K. (2003). Measurement issues in postpartum depression: Part 1. Anxiety as a feature of postpartum depression. Archives of Women's Mental Health, 6 , 51-57. doi:10.1007/s00737-002-0155-1

Ross, L. E., \& McLean, L. M. (2006). Anxiety disorders during pregnancy and the postpartum period: A systematic review. Journal of Clinical Psychiatry, 67, 1285-1298.

Royle, N. J., Hartley, I. R., \& Parker, G. A. (2002). Begging for control: When are offspring solicitation behaviours honest? Trends in Ecology \& Evolution, 17, 434-440.

Russell, E. J., Fawcett, J. M., \& Mazmanian, D. (2013). Risk of obsessivecompulsive disorder in pregnant and postpartum women: A meta-analysis. Journal of Clinical Psychiatry, 74, 377-385. doi:10.4088/ JCP.12r07917
Rutherford, H. J., Wallace, N. S., Laurent, H. K., \& Mayes, L. C. (2015). Emotion regulation in parenthood. Developmental Review, 36, 1-14. doi:10.1016/j.dr.2014.12.008

Sakbun, V., Koay, E., \& Bryant-Greenwood, G. (1987). Immunocytochemical localization of prolactin and relaxin C-peptide in human decidua and placenta. Journal of Clinical Endocrinology and Metabolism, $65,339$.

Saltzman, W., \& Abbott, D. H. (2009). Effects of elevated circulating cortisol concentrations on maternal behavior in common marmoset monkeys (Callithrix jacchus) Psychoneuroendocrinology, 34, 1222-1234. doi:10.1016/ j.psyneuen.2009.03.012

Saltzman, W., \& Maestripieri, D. (2011). The neuroendocrinology of primate maternal behavior. Progress in Neuro-Psychopharmacology and Biological Psychiatry, 35, 1192-1204. doi:10.1016/j.pnpbp.2010.09.017

Scatena, C. D., \& Adler, S. (1998). Characterization of a human-specific regulator of placental corticotropin-releasing hormone. Molecular Endocrinology, 12, 1228-1240.

Schlomer, G. L., Del Giudice, M., \& Ellis, B. J. (2011). Parent-offspring conflict theory: An evolutionary framework for understanding conflict within human families. Psychological Review, 118, 496-521.

Schrader, M., \& Travis, J. (2009). Do embryos influence maternal investment? Evaluating maternal-fetal coadaptation and the potential for parent-offspring conflict in a placental fish. Evolution, 63, 2805-2815.

Schulte, H. M., Weisner, D., \& Allolio, B. (1990). The corticotrophin releasing hormone test in late pregnancy: Lack of adrenocorticotrophin and cortisol response. Clinical Endocrinology (Oxford), 33, 99-106.

Seltzer, L. J., \& Ziegler, T. E. (2007). Non-invasive measurement of small peptides in the common marmoset (Callithrix jacchus): A radiolabeled clearance study and endogenous excretion under varying social conditions. Hormones and Behavior, 51, 436-442.

Sharma, V. (2003). Role of sleep loss in the causation of puerperal psychosis. Medical Hypotheses, 61, 477-481.

Sharma, V., Xie, B., Campbell, M. K., Penava, D., Hampson, E., Mazmanian, D., \& Pope, C. J. (2014). A prospective study of diagnostic conversion of major depressive disorder to bipolar disorder in pregnancy and postpartum. Bipolar Disorder, 16, 16-21. doi:10.1111/bdi.12140

Shingo, T., Gregg, C., Enwere, E., Fujikawa, H., Hassam, R., Geary, C., . . . Weiss, S. (2003). Pregnancy-stimulated neurogenesis in the adult female forebrain mediated by prolactin. Science, $299,117-120$. doi:10.1126/science. 1076647

Silber, M., Larsson, B., \& Uvnas-Moberg, K. (1991). Oxytocin, somatostatin, insulin and gastrin concentrations vis-a-vis late pregnancy, breastfeeding and oral contraceptives. Acta Obstetricia et Gynecologica Scandinavica, 70, 283-289.

Siler-Khodr, T. M., Khodr, G. S., \& Valenzuela, G. (1984). Immunoreactive gonadotropin-releasing hormone level in maternal circulation througout pregnancy. American Journal of Obstetrics and Gynecology, 150, 376-379. doi:10.1016/S0002-9378(84)80142-8

Sit, D., Rothschild, A. J., \& Wisner, K. L. (2006). A review of postpartum psychosis. Journal of Women's Health (Larchmt), 15, 352-368. doi:10.1089/jwh.2006.15.352

Skrundz, M., Bolten, M., Nast, I., Hellhammer, D. H., \& Meinlschmidt, G. (2011). Plasma oxytocin concentration during pregnancy is associated with development of postpartum depression. Neuropsychopharmacology, 36, 1886-1893. doi:10.1038/npp.2011.74

Slattery, D. A., \& Neumann, I. D. (2008). No stress please! Mechanisms of stress hyporesponsiveness of the maternal brain. Journal of Physiology, 586, 377-385. doi:10.1113/jphysiol.2007.145896

Smith, C. A., \& Farrington, D. P. (2004). Continuities in antisocial behavior and parenting across three generations. Journal of Child Psychology and Psychiatry, 45, 230-247.

Sroufe, L. A. (2013). The promise of developmental psychopathology: Past and present. Development and Psychopathology, 25(4, Pt. 2), 1215-1224. doi:10.1017/S0954579413000576

Strauss., J. F., III, Barbieri, R. L., \& Macy Ladd, K. (Eds.) (2014). Yen \& Jaffee's reproductive endocrinology (7th ed.) Philadelphia: Saunders.

Swain, J. E., Ho, S. S., Rosenblum, K. L., Morelen, D., Dayton, C. J., \& Muzik, M. (2017). Parent-child intervention decreases stress and increases maternal brain activity and connectivity during own baby-cry: An exploratory study. Development and Psychopathology, 29, 535553. doi:10.1017/S0954579417000165

Swain, J. E., Lorberbaum, J. P., Kose, S., \& Strathearn, L. (2007). Brain basis of early parent-infant interactions: Psychology, physiology, and in vivo 
functional neuroimaging studies. Journal of Child Psychology and Psychiatry, 48, 262-287. doi:10.1111/j.1469-7610.2007.01731.x

Swain, J. E., Tasgin, E., Mayes, L. C., Feldman, R., Constable, R. T., \& Leckman, J. F. (2008). Maternal brain response to own baby-cry is affected by cesarean section delivery. Journal of Child Psychology and Psychiatry, 49, 1042-1052. doi:10.1111/j.1469-7610.2008.01963.x

Tan, X. W., Liao, H., Sun, L., Okabe, M., Xiao, Z. C., \& Dawe, G. S. (2005). Fetal microchimerism in the maternal mouse brain: A novel population of fetal progenitor or stem cells able to cross the blood-brain barrier? Stem Cells, 23, 1443-1452. doi:10.1634/stemcells.2004-0169

Tebeka, S., Strat, Y. L., \& Dubertret, C. (2016). Developmental trajectories of pregnant and postpartum depression in an epidemiologic survey. Journal of Affective Disorders, 203, 62-68. doi:10.1016/j.jad.2016.05.058

Thornberry, T. P., Freeman-Gallant, A., Lizotte, A. J., Krohn, M. D., \& Smith, C. A. (2003). Linked lives: The intergenerational transmission of antisocial behavior. Journal of Abnormal Child Psychology, 31, 171-184.

Thornhill, R., \& Furlow, B. (1998). Stress and human reproductive behavior: Attractiveness, women's sexual development, postpartum depression, and baby's cry. Advances in the Study of Behavior, 27, 319-369.

Tkachenko, O., Shchekochikhin, D., \& Schrier, R. W. (2014). Hormones and hemodynamics in pregnancy. International Journal of Endocrinology and Metabolism, 12, e14098.

Torgersen, K. L., \& Curran, C. A. (2006). A systematic approach to the physiologic adaptations of pregnancy. Critical Care Nursing Quarterly, 29, 2-19.

Toth, S. L., \& Cicchetti, D. (2010). The historical origins and developmental pathways of the discipline of developmental psychopathology. Israel Journal of Psychiatry and Related Sciences, 47, 95-104.

Trivers, R. L. (1974). Parent-offspring conflict. American Zoologist, 14, 249-264.

Tuckey, R. C. (2005). Progesterone synthesis by the human placenta. Placenta, 26, 273-281.

Uguz, F., Akman, C., Kaya, N., \& Cilli, A. S. (2007). Postpartum-onset obsessive-compulsive disorder: Incidence, clinical features, and related factors. Journal of Clinical Psychiatry, 68, 132-138.

Vale, W., Spiess, J., Rivier, C., \& Rivier, J. (1981). Characterization of a 41residue ovine hypothalamic peptide that stimulates secretion of corticotropin and $\beta$-endorphin. Science, 213, 1394-1397.

Vesga-Lopez, O., Blanco, C., Keyes, K., Olfson, M., Grant, B. F., \& Hasin, D. S. (2008). Psychiatric disorders in pregnant and postpartum women in the United States. Archives of General Psychiatry, 65, 805-815. doi:10.1001/archpsyc.65.7.805

Vierin, M., \& Bouissou, M. F. (2001). Pregnancy is associated with low fear reactions in ewes. Physiology and Behavior, 72, 579-587.
Viguera, A. C., Nonacs, R., Cohen, L. S., Tondo, L., Murray, A., \& Baldessarini, R. J. (2000). Risk of recurrence of bipolar disorder in pregnant and nonpregnant women after discontinuing lithium maintenance. American Journal of Psychiatry, 157, 179-184. doi:10.1176/appi.ajp.157.2.179

Viguera, A. C., Whitfield, T., Baldessarini, R. J., Newport, D. J., Stowe, Z., Reminick, A., . . Cohen, L. S. (2007). Risk of recurrence in women with bipolar disorder during pregnancy: Prospective study of mood stabilizer discontinuation. American Journal of Psychiatry, 164, 1817-1824; quiz 1923. doi:10.1176/appi.ajp.2007.06101639

Wartella, J., Amory, E., Lomas, L. M., Macbeth, A., McNamara, I., Stevens, L., . . Kinsley, C. H. (2003). Single or multiple reproductive experiences attenuate neurobehavioral stress and fear responses in the female rat. Physiology and Behavior, 79, 373-381.

Wieck, A., Kumar, R., Hirst, A. D., Marks, M. N., Campbell, I. C., \& Checkley, S. A. (1991). Increased sensitivity of dopamine receptors and recurrence of affective psychosis after childbirth. BMJ, 303, 613-616.

Williams, D. (2003). Pregnancy: A stress test for life. Current Opinion in Obstetrics and Gynecology, 15, 465-471.

Williams, G. C. (1966). Adaptation and natural selection: A critique of some current evolutionary thought. Princeton, NJ: Princeton University Press.

Wisner, K. L., Peindl, K. S., Gigliotti, T., \& Hanusa, B. H. (1999). Obsessions and compulsions in women with postpartum depression. Journal of Clinical Psychiatry, 60, 176-180.

Yim, I. S., Glynn, L. M., Dunkel Schetter, C., Hobel, C. J., Chicz-DeMet, A., \& Sandman, C. A. (2009). Risk of postpartum depressive symptoms with elevated corticotropin-releasing hormone in human pregnancy. Archives of General Psychiatry, 66, 162-169. doi:10.1001/archgenpsychiatry. 2008.533

Yim, I. S., Tanner Stapleton, L. R., Guardino, C. M., Hahn-Holbrook, J., \& Dunkel Schetter, C. (2015). Biological and psychosocial predictors of postpartum depression: Systematic review and call for integration. Annual Review of Clinical Psychology, 11, 99-137. doi:10.1146/annurevclinpsy-101414-020426

Yonkers, K. A., Wisner, K. L., Stowe, Z., Leibenluft, E., Cohen, L., Miller, L., ... Altshuler, L. (2004). Management of bipolar disorder during pregnancy and the postpartum period. American Journal of Psychiatry, 161, 608-620. doi:10.1176/appi.ajp.161.4.608

Zambaldi, C. F., Cantilino, A., Montenegro, A. C., Paes, J. A., de Albuquerque, T. L., \& Sougey, E. B. (2009). Postpartum obsessive-compulsive disorder: Prevalence and clinical characteristics. Comprehensive Psychiatry, 50, 503-509. doi:10.1016/j.comppsych.2008.11.014

Zeng, X. X., Tan, K. H., Yeo, A., Sasajala, P., Tan, X., Xiao, Z. C., . . . Udolph, G. (2010). Pregnancy-associated progenitor cells differentiate and mature into neurons in the maternal brain. Stem Cells and Development, 19, 1819-1830. doi:10.1089/scd.2010.0046 